\title{
Articles
}

\section{Translating Filártiga: \\ A Comparative and \\ International Law Analysis \\ of Domestic Remedies \\ For International Human \\ Rights Violations}

\section{Beth Stephens $^{\dagger}$}

I. INTRODUCTION.

II. TEE U.S. EXPERIENCE: WHY FILÁRT7GA WORKS IN THE UNITED STATES...................................6

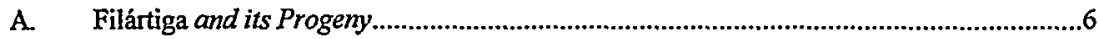

B. Civil Litigation in the U.S. Legal System ..................................................................10

1. Subject Matter Jurisdiction, Personal Jurisdiction, and Choice of Law ...............10

2. A Tradition of Public Interest and Impact Litigation .........................................12

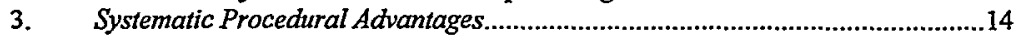

III. A COMPARATIVE ANALYSIS: WHY FILÁRTTGA DOES NOT TRANSLATE LITERALLY .......................17

A. Civil/Criminal Links .............................................................................................18

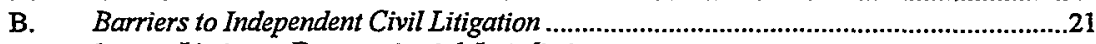

1. Limits on Extraterritorial Jurisdiction ..............................................................22

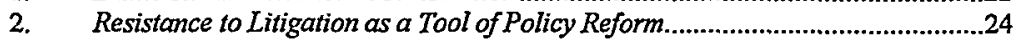

3. Procedural Hurdles to Civil Litigation ..............................................................27

IV. TRANSLATING FILARTIGA: A MúLTINATIONAL APPROACH TO DOMESTIC REMEDIES ....................34

A. Transnational Law Litigation: Contextualizing Filártiga.............................................35

B. Universal Jurisdiction over Transnational Law Litigation .............................................39

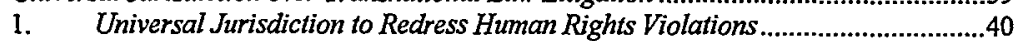

2. Dismantling the Criminal/Civil Divide ............................................................44

3. The Right to Compensation for International Human Rights Violations..................46

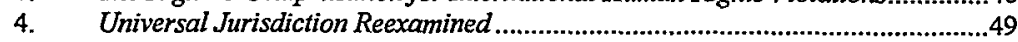

C. A New Convention: Preserving Civil Claims for Human Rights Abuses ..............................53

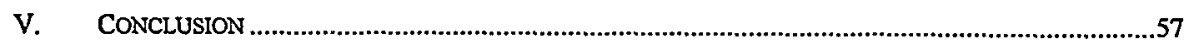

$\dagger$ Associate Professor of Law, Rutgers-Camden School of Law. Thanks to William Aceves, Ari Afilalo, Roger Clark, Jennifer Green, Claudia Halper, Michael Ratner, Elizabeth van Schaack, Peter Weiss, Chanaka Wickremasinghe, and Saman Zia-Zarifi for comments on an earlier draft, as well as to my Rutgers-Camden research assistants, Mellany Alio and Mark Morgan. I also thank the John D. and Catherine T. MacArthur Foundation for a grant which supported my initial work on this topic. Finally, my special appreciation to the many colleagues at international conferences, colloquia and workshops who have shared with me both their puzzlement and their respect for civil human rights litigation as developed in the United States. Through many conversations about concrete procedural differences and less tangible cultural gaps, I have developed the "translation" theory discussed in this article. All errors, of course, are mine. 


\section{INTRODUCTION}

Human rights activists, litigators, and scholars the world over are actively seeking means to hold accountable those responsible for egregious human rights abuses. Given the absence of effective international mechanisms, enforcement generally occurs within domestic legal systems. In most of the world, such enforcement efforts focus on criminal prosecution of perpetrators. Most dramatically, Chilean General Augusto Pinochet was arrested in England in 1998 and held for extradition to Spain to face criminal charges. ${ }^{1}$ Criminal cases have been prosecuted across Europe and in Africa as well. By contrast, efforts in the United States have focused on a unique line of civil human rights litigation. Individuals such as Philippine dictator Ferdinand Marcos and Bosnian Serb leader Radovan Karadzic have been sued, along with multinational corporations such as Unocal Oil and Royal Dutch Petroleum. Had General Pinochet come to the United States instead of to England, he most likely would have been sued, not arrested.

Civil human rights litigation in the United States began in 1980 with the Second Circuit's decision in Filártiga v. Peña-Irala. ${ }^{2}$ Since that decision, a series of cases has further developed U.S. civil remedies for international human rights violations. The Filártiga precedent permits federal courts to adjudicate allegations of gross human rights violations, even when the abuses take place in a foreign country. Lauded by many scholars and advocates in the United States, the doctrine has spawned books, symposia, and hundreds of law review articles in U.S. journals. ${ }^{3}$ Indeed, for international law scholars and practitioners in the United States, the development of a civil remedy for international human rights violations has been one of the most exciting and closely watched developments of the last two decades.

Outside of the United States, the global campaign to press criminal prosecutions for international human rights violations has gathered strength over the past ten years. Ad hoc international criminal tribunals have prosecuted individuals for violations committed in the former Yugoslavia and

1. Although the English courts upheld the validity of Spain's request to extradite Pinochet, he was eventually released on a finding that he was medically unfit to stand trial. For a general discussion of the Pinochet extradition battle, see Michael Byers, The Law and Politics of the Pinochet Case, 10 DUKE J. COMP. \& INT'L L. 415 (2000).

2. 630 F.2d 876 (2d Cir. 1980) (holding that relatives of a young man tortured to death in Paraguay by a Paraguayan police officer could obtain damages for this violation of international law).

3. A Westlaw search for "Filartiga" in August 2001, for example, tumed up 900 references in the Journal and Law Review database, with articles addressing a range of historical, constitutional, procedural, and human rights issues. Over forty of these references had been added since February 2001 .

My own contribution to this literature includes a book, BETH STEPHENS \& MICHAEL RATNER, INTERNATIONAL HUMAN RIGHTS LITIGATION IN U.S. COURTS (1996), and several articles, including Federalism and Foreign Affairs: Congress's Power to "Define and Punish . . O Offenses Against the Law of Nations," 42 WM. \& MARY L. REV. 447 (2000) [hereinafter Federalism and Foreign Affairs]; The Law of Our Land: Customary International Law as Federal Lav After Erie, 66 FoRDHAM L. REV. 393 (1997) [hereinafter The Law of Our Land]; and Expanding Remedies for Human Rights Abuses: Civil Litigation in Domestic Courts, 40 GERMAN Y.B. INT'L L. 117 (1997) [hereinafter Expanding Remedies]. In addition, as an attorney with the Center for Constitutional Rights and the Center for Justice and Accountability, I have been involved in many of the post-Filartiga cases as a litigator, amicus, or consultant. 
Rwanda. Domestic courts have asserted universal jurisdiction to prosecute international crimes committed in other countries. Dozens of nations have ratified the statute for a permanent International Criminal Court. In the course of this criminal law endeavor, however, scholars and activists abroad rarely refer to Filártiga as a relevant precedent. Filártiga has been cited in only a handful of foreign judicial opinions, none of which actually applied the doctrine, ${ }^{4}$ and commentary remains sparse. ${ }^{5}$ Civil human rights litigation generally continues to be viewed as a peculiarly U.S. phenomenon.

This apparent disinterest in U.S. civil litigation is particularly striking given that U.S. jurisprudence refers repeatedly to international law: U.S. courts and commentators stress that these decisions are consistent with international law, if not also mandated by that law. U.S. attorneys regularly ask why there have been no Filártiga lawsuits in other countries, questioning why human rights litigators in other legal systems have not utilized this important tool on behalf of victims of human rights abuses. Despite the extensive U.S. literature on the doctrine, there has been virtually no analysis of this question, no effort to explain this striking difference in legal strategies.

The key to unraveling this puzzle is to recognize that it reflects a misconception of the interrelationship between international law and varied domestic legal systems. Exact duplicates of Filártiga human rights litigation are unlikely in most legal systems because of differences in legal procedure and legal culture. But criminal and administrative proceedings and civil suits based on domestic tort claims respond to the same international law concerns as Filártiga lawsuits. These similarities are overlooked both within the United States and abroad, leading to the mistaken belief that we are engaged in significantly different legal enterprises. To the contrary, each of these procedures reflects the "translation" into domestic law of identical international law mandates. Our inability to understand each other's litigation strategies reflects a communication failure, a failure to recognize how legal claims seeking accountability must be adapted for varied legal systems. As a

4. I have uncovered citations to Filártiga in only two cases outside of the United States: AlAdsani v. Government of Kuwait, I07 I.L.R. 536 (Eng. C.A. 1996) (suit against Kuwaiti government and three individuals for torture in Kuwait and threats in England), and Regina $v$. Bow Street Metropolitan Stipendiary Magistrate, ex parte Pinochet, [1999] 2 W.L.R. 827 (H.L.) (the Pinochet decision).

5. The first extensive analysis of Filärtiga in print outside of the United States appeared in 2001. TORTURE AS TORT (Craig Scott ed., 2001) (exploring the possibility of civil claims for torture); see also HUMAN RIGHTS COMMTTEE, INIERNATIONAL LAW ASSOCIATION (BRTTISH BRANCH), REPORT ON CIVIL ACTIONS IN THE ENGLISH COURTS FOR SERIOUS HUMAN RIGHTS VIOLATIONS ABROAD, reprinted in 2001 EUR. HUM. RTS. L. REV. 129 [hereinafter BRITISH ILA REPORT] (discussing the possibility of civil human rights litigation in England).

Aside from these recent contributions, there have been only a handful of articles in journals outside of the United States. Examples include Jane L. Garwood-Cutler \& R. John Pritchard, Domestic Adjudication of International Law Violations, 12 NEW L.J. 527 (1996); Gerald P. McGinley, Of Pirates and Privateers: The Historical Background of the Alien Tort Claims Act with Some Suggestions for its Future Use, 21 ANGLO-AM. L. REV. 138 (1992); Roger O'Keefe, Civil Actions in U.S. Courts in Respect of Human Rights Abuses Committed Abroad: Would the World's Oppressors Be Wise To Stay at Home?, 9 R.A.D.I.C. (AFRICAN J. INI'L \& COMP. L.) 15 (1997); and my own article in the German Yearbook of International Law, Expanding Remedies, supra note 3. 
result, we have failed to recognize the common international law foundation underlying the Filártiga doctrine and its procedural cousins around the world.

Translation in this context refers to the process by which a common concept-accountability for human rights abuses-is expressed in the legal "language" of each domestic legal system. Just as rigid, word-by-word translations rarely capture the meaning of a text in a foreign language, so the mechanical transfer of legal procedures from one system to another is rarely effective. Instead, common goals must be realized through procedures appropriate to each national system. The translator thereby achieves "interpretive fidelity," a representation of the intended meaning appropriate to the changed context in which such meaning must operate. ${ }^{6}$

Translation of Filartiga requires recognition of the dual aspects of the Filártiga doctrine-a broad approach seeking justice for victims of human rights abuses, and a narrow core that focuses on providing a forum for civil human rights litigation in whatever location a perpetrator can be found. The broad doctrine encompasses a wide range of administrative and judicial remedies for claims that may be styled as human rights violations, torts, or crimes, against both domestic and foreign defendants, for violations committed both at home and abroad. There have been broad Filártiga cases in many countries, as each legal system translates these goals into its local legal proceedings.

In the United States, this translation leads to core Filártiga cases-civil lawsuits for human rights violations committed abroad, suing any perpetrator who can be brought before U.S. courts. The core doctrine relies on the same principles that underlie criminal prosecutions in other legal systems, namely, that any nation can, and should, hold accountable those who abuse certain internationally protected human rights. Whereas such efforts in other systems might be restricted to criminal prosecutions, several procedural and cultural characteristics of the U.S. legal system lead human rights lawyers and activists here to translate these concepts into civil litigation. There have been no core Filártiga cases outside the United States because civil lawsuits on the Filártiga model are a product of several U.S. legal principles that do not

6. Lawrence Lessig, Fidelity in Translation, 71 TEX. L. REV. 1165 (1993) (applying the concept to constitutional interpretation). As Lessig notes, literary translators regularly confront the difficulties of "translating" concepts from one linguistic and cultural context to another. Id. at 11891203; see also ALASDAIR MACINTYRE, WHOSE JUSTICE? WHICH RATIONALITY? 373 (1988) (stating that translators must recognize that linguistic expression reflects "beliefs, institutions, and practices" at a "particular time and place"); Arthur Schopenhauer, On Language and Words (Peter Mollenhauer trans.), in THEORIES OF TRANSLATION: AN ANTHOLOGY OF ESSAYS FROM DRYDEN TO DERRIDA 32 (Rainer Schulte \& John Biguenet eds., 1992) ("Not every word in one language has an exact equivalent in another. Thus, not all concepts that are expressed through the words of one language are exactly the same as the ones that are expressed through the words of another."); T. Tymoczko, Translation and Meaning, in MEANING AND TRANSLATION 29, 36 (F. Guenthner \& M. Guenthner-Reutter eds., 1978) ("What a language can mean depends upon the environment of the language users ....").

In a recently published essay, Craig Scott used the concept of translation to refer to the issues triggered by viewing an international human rights violation as a domestic tort, asking whether a human rights norm can be "translated" into a civil cause of action in a domestic legal system. Craig Scott, Translating Torture into Transnational Tort: Conceptual Divides in the Debate on Corporate Accountability for Human Rights Harms, in TORTURE AS TORT, supra note 5, at 45. 
translate easily into other legal languages. In other countries, however, distinct domestic procedures are used to accomplish the same results.

My first goal in this Article is to emphasize these commonalities. Victims of human rights abuses around the world seek comparable results through varied procedural models, tailored to the requirements of their local legal systems. These overlapping issues and goals are often overlooked, a result of our failure to understand each other's legal systems. Second, I explore differences in civil and criminal procedure that create both structural obstacles and cultural resistance to civil human rights litigation but also make other options more advantageous than in the United States. We cannot understand each other's varied approaches to similar problems until we recognize what we share while also acknowledging our differences.

My final goal is to apply these insights to an analysis of universal jurisdiction over civil remedies for human rights abuses. Universal jurisdiction is a key aspect of the accountability movement, permitting, and at times requiring, domestic legal systems to bring perpetrators to justice. Although widely discussed as an authorization for international and domestic criminal prosecutions, few outside of the United States have considered the application of universal jurisdiction to civil claims. My review of both the history and the underlying aims of universal jurisdiction demonstrates that a rigid distinction between civil and criminal remedies is unfounded. An exclusive focus on criminal prosecution is the result of a translation gap, a failure to recognize that civil liability for human rights abuses represents the translation of international accountability principles into a strategy appropriate to a particular domestic legal system. Universal jurisdiction provides the international law foundation for domestic assertions of jurisdiction over all categories of claims for human rights violations, including Filártiga cases.

To accomplish these interrelated goals, I begin Part II with an account of the current practice in the United States, providing an overview of U.S. civil litigation on the model of Filártiga and its development to cover additional human rights violations and a broad range of defendants. I explain how procedural rules peculiar to the United States combine with the unique U.S. legal culture to make such cases both possible and attractive in the United States. In Part III, I look at the very different rules in other legal systems, where civil human rights claims have been brought as adjuncts to criminal prosecutions but not as independent actions, examining how structural differences in domestic legal systems make independent civil human rights actions less likely outside the United States.

Part IV presents a detailed argument for universal jurisdiction over civil human rights claims. Such cases are part of the diverse range of transnational law litigation: Different legal systems achieve common goals through an assortment of legal mechanisms, including public as well as private, civil and administrative as well as criminal. Civil claims are an important tool of human rights enforcement, serving the needs of victims of human rights abuses. I apply the conclusions of my comparative discussion as well as this international law analysis to argue that the assertion of jurisdiction over civil 
human rights claims is an appropriate translation of universal jurisdiction principles into domestic legal systems.

I conclude by addressing the implications of this conclusion to an immediate, pressing concern-ongoing negotiations to draft an international convention governing civil jurisdiction and enforcement of judgments. As originally drafted, the convention made no provision for civil claims for human rights violations, failing to recognize that such claims fall within the reach of universal jurisdiction. After concerted efforts by international human rights organizations, the current working draft includes a proposal to protect civil human rights claims, but there is as yet no consensus on this issue. It is crucial that we work quickly to understand our different domestic procedures, in order to avoid limitations based solely on translation failures. An international agreement that specifically protects the right to seek civil remedies for human rights abuses would add an important tool to the accountability movement.

Victims of human rights violations the world over face disheartening struggles for justice as they seek remedies for their injuries, punishment of those responsible, and assurance that future abuses will be deterred. They utilize a wide range of international and domestic mechanisms in that quest, including both criminal and civil actions. Through an understanding of the varied means by which common goals can be attained, we contribute to the development of these remedies and strengthen accountability principles.

\section{THE U.S. EXPERIENCE: WHY FILÁRTIGA WORKS IN THE UNITED STATES}

The successful series of U.S. federal court cases seeking civil damages for human rights abuses relies in part upon a series of procedures and practices rarely found outside of the United States. After an overview of Filartiga and the line of cases that have followed its precedent, I will detail the peculiarities that make these cases legally possible and logistically practical in the U.S. legal system.

\section{A. Filártiga and its Progeny}

The modern cases in which U.S. federal courts assert jurisdiction over human rights violations committed by aliens against aliens in their home country began in 1980 with the Second Circuit decision in Filártiga v. PeñaIrala. ${ }^{7}$ Joelito Filártiga, a 17-year-old Paraguayan, was tortured to death in Paraguay in 1976 by Americo Norberto Peña-Irala, a Paraguayan police officer, in retaliation for his father's political opposition to the military dictatorship. Peña-Irala came to the United States in 1978 and was living in New York City at the time the case was filed. In 1979, Joelito's sister and father sued Peña-Irala for his torture and death, filing suit in the Eastern District of New York under the Alien Tort Claims Act (ATCA). ${ }^{8}$

7. 630 F.2d 876 (2d Cir. 1980). For the full factual background of the case, see $i d$ at $878-80$.

8. 28 U.S.C. $\S 1350$ (1994). 
Originally enacted as part of the first Judiciary Act, ${ }^{9}$ the statute as currently codified states: "The district courts shall have original jurisdiction of any civil action by an alien for a tort only, committed in violation of the law of nations ...."10 An eighteenth-century opinion by the Attorney General of the United States noted that the statute afforded federal court jurisdiction over a civil suit for a violation of the law of nations, in that case a breach of neutrality. ${ }^{11}$ For about two hundred years thereafter, the statute was largely ignored, rarely cited, and relied upon in only two cases. ${ }^{12}$

With only this limited historical record before it, the key issue the court faced in Filártiga was determining whether torture fit the statute's requirement of a "tort . . . in violation of the law of nations." The district court, relying on dicta in earlier Second Circuit decisions, concluded that a government's mistreatment of its own citizens was not a violation of the law of nations. ${ }^{13}$ The Second Circuit reversed, finding that the ATCA incorporated the law of nations in its current-not its historical-form, and that modern international law prohibits human rights abuses committed by government officials against their own citizens. After canvassing United Nations declarations, regional human rights agreements, U.S. government statements, and the conclusions of international law scholars, the court concluded that "official torture is now prohibited by the law of nations" and therefore triggers jurisdiction under the ATCA. ${ }^{14}$

Since 1980, a series of decisions has slowly developed the jurisdictional reach of the Alien Tort Claims Act. Federal courts have assumed jurisdiction over cases between aliens alleging abuses such as genocide, war crimes, summary execution, disappearance, and arbitrary detention, as well as torture. ${ }^{15}$ In each case, the court examined international and domestic sources to determine whether the human rights violation met the statute's standard.

9. Judiciary Act of 1789 , ch. $20, \S 9(\mathrm{~b}), 1$ Stat. $73,77$.

10. 28 U.S.C. $\$ 1350$ (1994).

11. 1 Op. Att'y Gen. 57, 59 (1795) (finding that ATCA grants civil remedy to aliens injured by plundering of British colony in violation of law of nations); see also 26 Op. Att'y Gen. 250, 253 (1907) (stating that ATCA "provide[s] a forum and a right of action" when aliens sue for damages caused in Mexico by the tortious diversion of water in the Rio Grande river if such act violates the law of nations).

12. For the history of ATCA claims prior to Filartiga, see Kenneth C. Randall, Federal Jurisdiction over International Law Claims: Inquiries into the Alien Tort Claims Statute, 18 N.Y.U. J. INT'L L. \& POL. 1, 4-5 nn.15-17 (1985) (reporting that twenty-one cases claimed ATCA jurisdiction prior to Filärtiga). Jurisdiction was sustained in Bolchos v. Darrell, 3 F.Cas. 810 (D.S.C. 1795), a case involving "property" rights over slaves seized as a prize of war, and Adra v. Clift, 195 F.Supp. 857 (D. Md. 1961), an international custody dispute.

13. Civ. No. 79-917 (E.D.N.Y. May 15, 1979), summarized in Filórtiga, 630 F.2d at 880.

14. 630 F.2d at 884 .

15. See, e.g., Kadic v. Karadzic, 70 F.3d 232 (2d Cir. 1995), cert. denied, 518 U.S. 1005 (1996) (genocide, war crimes, summary execution, torture); Abebe-Jira v. Negewo, 72 F.3d 844 (11th Cir. 1996), cert. denied, 519 U.S. 830 (1996) (torture); Trajano v. Marcos, 978 F.2d 493 (9th Cir. 1992), cert. denied, 508 U.S. 972 (1993) (summary execution); Xuncax v. Gramajo, 886 F. Supp.162 (D. Mass. 1995) (summary execution, torture, disappearance, cruel, inhuman or degrading treatment); Forti v. Suarez-Mason, 672 F.Supp. 1531 (N.D. Cal. 1987), 694 F.Supp. 707 (N.D. Cal. 1988) (on reconsideration) (summary execution, torture, disappearance). 
Jurisdiction has been found when the alleged tort satisfies the international law definition of a universally prohibited offense.

The courts have also looked to international law to define who can be held liable for the violation. Thus, since the international law definition of torture requires some public action, ${ }^{16}$ U.S. cases have limited torture claims to those that allege that the defendant acted under color of official authority or in complicity with public officials. ${ }^{17}$ Since genocide is defined as an international violation when committed by private persons, ${ }^{18}$ claims of genocide have been accepted even in the absence of state action. ${ }^{19}$ The categories of defendants subject to suit now includes commanding officers, officials of de facto governments, U.S. and local government officials, and corporations. ${ }^{20}$ In an important limitation, however, the Supreme Court has held that ATCA claims do not create an automatic exception to the statutory definition of foreign sovereign immunity; that is, foreign states cannot be sued under the statute unless the claim falls within one of the standard exceptions to such immunity. ${ }^{21}$

Much of the scholarly commentary on the ATCA concerns the intent of the statute, focusing on whether Congress intended to create a cause of action and federal jurisdiction over violations of customary international law committed by non-citizens outside of the United States. All courts that have decided the issue have concluded that the statute authorizes suits in federal court when its facial requirements are met; that is, an alien can sue for a tort in violation of international law, no matter where committed, so long as the court has personal jurisdiction over the defendant. ${ }^{22}$ For the purposes of this Article,

16. The Convention Against Torture defines "torture" as certain acts committed "by or at the instigation of or with the consent or acquiescence of a public official or other person acting in an official capacity." Convention Against Torture and Other Cruel, Inhuman or Degrading Treatment or Punishment, Dec. 10, 1984, art. 1(1), G.A. Res. 39/46, U.N. GAOR, 39th Sess., Supp. No. 51, at 197, U.N. Doc. A/39/46 (1984) (entered into force for the United States Nov. 20, 1994) thereinafter Torture Convention].

17. Kadic, 70 F.3d at 243 (explaining that torture is proscribed by international law "only when committed by state officials or under color of law").

18. Convention on the Prevention and Punishment of the Crime of Genocide, Dec. 9, 1948, art. 4, 102 Stat. 3045, 78 U.N.T.S. 277 (entered into force for the United States Feb. 23, 1989) [hereinafter Genocide Convention] ("Persons committing genocide . . . shall be punished, whether they are constitutionally responsible rulers, public officials or private individuals.").

19. Kadic, 70 F.3d at 241-42.

20. See, e.g., Trajano, 978 F.2d 493 (commanding officer/former head of state); Kadic, 70 F.3d 232 (head of de facto state); Jama v. INS., 22 F.Supp. 2d 353 (D.N.J. 1998) (U.S. officials and private corporation); Martinez v. City of Los Angeles, 141 F.3d 1373 (9th Cir. 1998) (local government officials); Wiwa v. Royal Dutch Petroleum Co., 226 F.3d 88 (2d Cir. 2000), cert. denied, 121 S. Ct. 1402 (2001) (corporation).

21. Argentine Rep. v. Amerada Hess Shipping Corp., 488 U.S. 428 (1989) (refusing to recognize an exception to the Foreign Sovereign Immunities Act (FSIA), 28 U.S.C. $\S \S 1330,1602-11$ (1994), for claims of gross human rights abuses). For a contrary view, see the dissenting opinion of Judge Wald in Princz v. Federal Republic of Germany, 26 F.3d 1166, 1176-84 (D.C. Cir. 1994), in which she argues that the FSIA should not be read to bar civil suits for violations of universally accepted international norms.

22. See, e.g., Trajano, 978 F.2d at 499 ("We start with the face of the statute. It requires a claim by an alien, a tort, and a violation of international law."). The Supreme Court has never addressed the issue, but has repeatedly denied petitions for certiorari seeking review of this question. See supra notes $15 \& 20$. 
I assume that the courts have correctly interpreted the statute to afford jurisdiction and create a cause of action for violations of fundamental international norms as those norms evolve over time, regardless of whether those violations have a factual connection to the United States. ${ }^{23}$

Three modern statutes enacted in the past decade authorize civil claims related to those covered by the ATCA. The Torture Victim Protection Act (TVPA) creates a right to sue for torture or extrajudicial execution, extending that right to sue to U.S. citizens as well as aliens. ${ }^{24}$ As part of an anti-terrorism initiative, Congress has also authorized civil suits for victims of terrorism. ${ }^{25} \mathrm{~A}$ 1996 amendment to the Foreign Sovereign Immunities Act (FSIA) permits civil suits for torture, extrajudicial killing, and other abuses against a small group of foreign governments. ${ }^{26}$ The FSIA governs all litigation against foreign states in U.S. courts, authorizing such suits only when the claim falls within a handful of enumerated exceptions to immunity. ${ }^{27}$ The new exception permits suits by U.S. citizens, but only when the defendant government is on

23. I have argued for this result in prior articles; most scholars agree, although the point continues to be debated. Compare Stephens, Federalism and Foreign Affairs, supra note 3, at 520-24, 520-21 n.305 (citing cases and additional articles), and Stephens, The Law of Our Land, supra note 3 (discussing the role of customary international law in debate over ATCA), with Curtis A. Bradley \& Jack L. Goldsmith, Federal Courts and the Incorporation of International Law, 111 HARV. L. REV. 2260 (1998), and Curtis A. Bradley \& Jack L. Goldsmith, Customary International Law as Federal Common Law: A Critique of the Modern Position, 110 HARV. L. REV. 815 (1997). The most recent exchange on this issue is due to be published in a forthcoming issue of the Virginia Journal of International Law. Curtis A. Bradley, The Alien Tort Statute and Article III, 42 VA. J. INT'L L. (forthcoming 2002); William S. Dodge, The Constitutionality of the Alien Tort Statute: Some Observations on Text and Context, 42 VA. J. INT'L L. (forthcoming 2002).

Even if this interpretation of the ATCA is eventually rejected, civil claims for human rights abuses committed abroad would continue to be litigated in the United States pursuant to the three more recent statutes discussed in the following paragraph.

24. Torture Victim Protection Act [TVPA] of 1991, Pub. L. No. 102-256, 106 Stat. 73 (1992) (codified at 28 U.S.C. 1350 (2000)). The legislative history supports the Alien Tort Claims Act as interpreted by the Filórtiga court and stresses that the TVPA was not intended to supersede the ATCA. H.R. REP. NO. 367, 102d Cong, 2d Sess. 3, reprinted in 1992 U.S.C.C.A.N. 84, 86. The TVPA is limited by the requirement that the torture or extrajudicial execution be committed "under actual or apparent authority, or color of law, of any foreign nation." TVPA, §2(a). For an application of the TVPA in a case filed by a U.S. citizen, see Xuncax v. Gramajo, 886 F.Supp. 162, 176-78 (D. Mass. 1995) (adjudicating the claims of plaintiff Dianna Ortiz).

25. 18 U.S.C. $\$ 2333$ (1994) authorizes a U.S. national "injured in his or her person, property, or business by reason of an act of international terrorism" to sue for treble damages. Id. at $\S 2333$ (a). Two reported cases have upheld jurisdiction under this provision over claims of terrorism filed by relatives of U.S. citizens killed in Israel. Estate of Ungar v. Palestinian Authority, 153 F.Supp. 2d 76, 85 (D.R.I. 2001) (upholding subject matter jurisdiction over claims alleging that defendants were complicit in the shooting death of a U.S. citizen in Israel); Boim v. Quranic Literacy Institute, 127 F.Supp. 2d 1002 (N.D. Ill. 2000) (denying a motion to dismiss a claim by parents of a man killed in Israel who alleged that defendants had engaged in international terrorism by supplying funding to groups responsible for the attack).

26. The FSIA is codified at 28 U.S.C. $\$ \S 1330,1602-11$ (2001); this exception is codified at $\S$ 1605(a)(7) (introduced in 1994).

27. The exceptions are set forth in 28 U.S.C. $\S 1605(\mathrm{a})$; the broadest apply to torts committed within the United States and to certain commercial matters. The FSIA does permit human rights lawsuits to proceed where the claims fall within the statutory exceptions. See, e.g., Siderman de Blake v. Republic of Argentina, 965 F.2d 699 (9th Cir. 1992) (applying exceptions for waiver of immunity, extraterritorial torts having an impact in the United States, and expropriation of property); Letelier v. Republic of Chile, 488 F.Supp. 665 (D.D.C. 1980) (applying the tort exception to a claim arising out of the assassination of a political opponent within the United States). 
the U.S. government's list of foreign states designated as "state sponsor[s] of terrorism. ${ }^{28}$ The State Department has designated seven such countries, ${ }^{29}$ and judgments have been issued pursuant to the statute against both Cuba and Iran. ${ }^{30}$

These three modern statutes are clearly creatures of U.S. law: each provides U.S. statutory definitions of the underlying offenses and the permitted defendants. The legal regime governing the ATCA differs significantly, given that the statute incorporates international law and relies upon it to define the substance of the tort, including the actor who is subject to suit. Nevertheless, several key threshold questions are determined by U.S. law, including both personal and subject matter jurisdiction. ${ }^{31}$ In addition, U.S. courts routinely apply local procedural rules to all actions, no matter what law governs the substantive claim. The application of these standard U.S. jurisdictional and procedural rules to human rights complaints is crucial to understanding why core Filártiga cases flourish in the United States.

\section{B. Civil Litigation in the U.S. Legal System}

Several principles of jurisdiction and procedure make civil human rights cases both possible and practical in the United States. Understanding why we can litigate these cases here is the first step towards understanding the differences that make exact copies unlikely in other legal systems. The first set of issues concerns jurisdiction-both subject matter and personal jurisdiction-and choice of law. The second concerns legal culture: attitudes toward civil lawsuits as a tool for law reform and social impact. The third concerns the rules of litigation: discovery, damages, attorney fees, and the costs of public interest litigation. I will discuss each in turn in the following sections.

\section{Subject Matter Jurisdiction, Personal Jurisdiction, and Choice of} Law

U.S. federal courts are courts of limited jurisdiction, empowered to decide only the categories of cases authorized by the Constitution, and only if

28. 28 U.S.C. $\S 1605(\mathrm{a})(7)(\mathrm{A})(2001)$.

29. "State sponsors of international terrorism" are designated by section $6(\mathrm{j})(1)$ of the Export Administration Act of 1979, section 620A of the Foreign Assistance Act of 1961, or section 40(d) of the Arms Export Control Act. 22 U.S.C. § 7205(a) (2001). The foreign states designated sponsors of terrorism pursuant to the last statute are: Iran, Cuba, Syria, Iraq, Libya, Sudan, and North Korea. 22 C.F.R. $\S 126.1(d)(2001)$.

30. See, e.g., Elahi v. Iran, 124 F.Supp. $2 d 97$ (D.D.C. 2000); Flatow v. Iran, 999 F.Supp. 1 (D.D.C. 1998); Alejandre v. Cuba, 996 F.Supp. 1239 (S.D. Fla. 1997). Cases have also been filed against Iraq and Libya. E.g., Rein v. Socialist People's Libyan Arab Jamahiriya, 162 F.3d 748 (2nd Cir. 1998) (denying defendant's motion to dismiss); Daliberti v. Iraq, 97 F.Supp. 2 d 38 (D.D.C. 2000) (same).

31. Subject matter jurisdiction over ATCA cases does require a finding that the claim involves a tort in violation of international law, but, as explained in what follows, the framework in which that decision is applied is determined by U.S. constitutional and statutory rules governing the jurisdiction of the federal courts. 
Congress has implemented this potential jurisdiction through enabling legislation. The question of federal subject matter jurisdiction is solely an issue of the limited allocation of judicial authority to the federal courts. If a case falls within the provisions of the Constitution and Congress has authorized federal court jurisdiction, the inquiry ends; the requirement of subject matter jurisdiction has been satisfied. Moreover, Congress has the unquestioned authority to apply U.S. law, so long as the area falls within Congress's constitutional law-making powers.

Glaringly absent from this formulation is any requirement that the claim have any connection with the United States. Thus, the federal courts will adjudicate and apply U.S. law to cases involving people and events outside of the United States, so long as Congress has so authorized and the requirements of the Constitution are met. ${ }^{32}$ This, then, is the first key characteristic of the U.S. legal system: our federal courts assert jurisdiction and apply U.S. law as instructed by the Constitution and Congress, with no inherent limitations based on the relationship of the case to the forum. U.S. federal courts thus have jurisdiction over international human rights cases because Congress, through the ATCA and related statutes, has instructed them to decide such cases. Legal issues are decided according to the law indicated by Congress: international law for the ATCA, and U.S. law for the other statutes.

Of course, U.S. courts can only decide cases if they also have personal jurisdiction over the defendant. As to personal jurisdiction, U.S. courts face strict limits imposed by the Constitution and implementing statutes. ${ }^{33}$ Two rules, however, permit U.S. courts to assert jurisdiction more widely than permitted by many systems: general jurisdiction over persons who are

32. Extraterritorial application can only occur with "the affirmative intention of the Congress clearly expressed." Benz v. Compania Naviera Hidalgo, 353 U.S. 138, 146-47 (1957); see also American Banana Co. v. United Fruit Co., 213 U.S. 347, 357 (1909) (same). Given an ambiguous statute, the courts will presume that Congress did not intend to apply the statute to extraterritorial events. This presumption, however, is trumped by clear congressional intent. See Blackmer v. United States, 284 U.S. 421, 437 (1932) (holding that statutes are presumed not to apply extraterritorially unless Congress indicates the contrary).

33. Ironically, for the first 100 years of U.S. jurisprudence, rules of jurisdiction were derived from international law, with the Supreme Court treating the states as it would independent nations. See, e.g., Hall v. Lanning, 91 U.S. 160, 165 (1875); Andrew L. Strauss, Beyond National Law: The Neglected Role of the International Law of Personal Jurisdiction in Domestic Courts, 36 HARV. INT'L L.J. 373, 395-96 (1995) (explaining that U.S. courts historically applied international law to resolve jurisdictional problems among the states). International law limits on U.S. jurisdiction were followed except where otherwise mandated by the Constitution. See, e.g., Mills v. Duryee, 11 U.S. (7 Cranch) 481 (1813) (holding that the Full Faith and Credit Clause of the Constitution required exception to international rule that sovereign nations need not enforce judgments of foreign governments); D'Arcy v. Ketchum, 52 U.S. (11 How.) 165, 176 (1850) (holding that the Full Faith and Credit Clause was limited by the international rule that sovereign nations need not enforce a judgment where the foreign government issuing the judgment did not have personal jurisdiction over a defendant because neither the framers of the Constitution nor Congress intended "to overthrow this principle."); Gary B. Born, Reflections on Judicial Jurisdiction in International Cases, 17 GA. J. INT'L \& COMP. L. 1, 17-18 (1987). Since the Supreme Court decision in Pennoyer v. Neff, 95 U.S. 714 (1877), jurisdiction has been governed by the constitutional guarantee of due process, rather than by international rules. See Patrick J. Borchers, The Death of the Constitutional Law of Personal Jurisdiction: From Pennoyer to Burnham and Back Again, 24 U.C. DAvIS L. REV. 19, 23-24 (1990) (analyzing the constitutionalization of U.S. personal jurisdiction, starting with Pennoyer). 
transitorily present in the jurisdiction at the time of service and over corporations that have minimum contacts with the jurisdiction. Both of these rules apply equally to domestic and foreign defendants. ${ }^{34}$

Personal jurisdiction in core Filártiga lawsuits-suits against non-U.S. actors for violations committed outside of the United States-is, therefore, determined by U.S. courts according to the same structure governing the exercise of personal jurisdiction over domestic actors. ${ }^{35}$ The U.S. doctrines that permit assertions of jurisdiction over individuals served while within the district, and over corporations doing business in the forum, provide an opening for widespread application of the Filártiga doctrine within the United States.

\section{A Tradition of Public Interest and Impact Litigation}

The egregious violations that are the subject of civil human rights litigation constitute crimes, violent crimes. Labeling such acts as torts and seeking redress through private lawsuits provokes the concern that the events are thereby trivialized, that an affront against all of humanity has been reduced to an issue of money and financial compensation. ${ }^{36}$ This sense of the inadequacy of civil remedies is aggravated by the fact that the defendant does not face imprisonment and does not face the wrath of the entire community, as represented by a government prosecutor.

34. The Supreme Court has hinted that foreign defendants might be treated differently for personal jurisdiction analysis. Asahi Metal Industry Co., Ltd. v. Superior Court of California, 480 U.S. 102, 114 (1987) ("The unique burdens placed upon one who must defend oneself in a foreign legal system should have significant weight in assessing the reasonableness of stretching the long arm of personal jurisdiction over national borders."). Subsequent cases, however, have not developed this distinction. See Linda J. Silberman, Judicial Jurisdiction in the Conflict of Laws Course: Adding a Comparative Dimension, 28 VAND. J. TRANSNAT'L L. 389, 392-93 (1995) (noting that post-Asahi cases have applied the same standard to determine jurisdiction over both domestic and foreign defendants); Strauss, supra note 33, at 383-87 (criticizing application of domestic jurisdictional principles to cases involving foreign litigants).

35. The Second Circuit rejected in one sentence a challenge to the assertion of personal jurisdiction over Radovan Karadzic, who was served while visiting New York, stating simply, "Fed. $R$. Civ. P. 4(e)(2) specifically authorizes personal service of a summons and complaint upon an individual physically present within a judicial district of the United States, and such personal service comports with the requirements of due process for the assertion of personal jurisdiction." Kadic v. Karadzic, 70 F.3d 232, 247 (2d Cir. 1995), cert. denied, 518 U.S. 1005 (1996). In a similar case against a transnational corporation, the Second Circuit recently upheld general jurisdiction, applying the same "doing business" standard applied to U.S. corporations. Wiwa v. Royal Dutch Petroleum Co., 226 F.3d 88 (2d Cir. 2000), cert. denied, 121 S. Ct. 1402 (2001).

36. As stated by the judge who decided a case addressing genocide in Rwanda, "the defendant has engaged in conduct so inhuman that it is difficult to conceive of any civil remedy which can begin to compensate the plaintiffs for their loss or adequately express society's outrage at the defendant's actions." Mushikiwabo v. Barayagwiza, No. Civ. 94-3627, 1996 WL 164496 at *1 (S.D.N.Y. Apr. 9, 1996) (Martin, J.); see also LYAL S. SUNGA, INDIVIDUAL RESPONSIBILITY IN INTERNATIONAL LAW FOR SERIOUS HUMAN RIGHTS VIOLATIONS 113 (1992) (criticizing tort remedies for violations such as torture as "belittl[ing] the status of torture as an international crime"). During debates about the proposed International Criminal Court, some representatives argued that the Court should not be empowered to impose fines because monetary penalties were inadequate given the serious nature of the crimes that would be brought before the Court. Report of the Preparatory Committee on the Establishment of an International Criminal Court, U.N. GAOR, 51st Sess., Supp. No. 22A, Vol. I (Proceedings of the Preparatory Committee, March-April and August 1996), art. 47, at 63, U.N. Doc. A/51/22 (1996). 
Civil litigation in the United States, however, has long been used as a means of promoting social reform. Indeed, the Filártiga decision has been called the Brown v. Board of Education of transnational law litigation, invoking the legacy of the great civil rights cases that dismantled legal segregation across the United States. ${ }^{37}$ This may explain in part why U.S. lawyers and activists gravitate towards civil lawsuits for human rights violations: such litigation is an important part of our legal culture. Twentyfive years ago, Professor Chayes labeled such cases "public law litigation," stressing that these cases do not focus solely on private disputes, but aim as well at "the vindication of constitutional or statutory policies." 38 Indeed, in some public interest cases, "the subject matter of the lawsuit is not a dispute between private individuals about private rights, but a grievance about the operation of public policy. ${ }^{39}$ In the United States, we are generally comfortable with the concept that lawsuits seek remedies designed with an eye to the future. The goal of prospective relief supplants or complements the redress of past grievances. ${ }^{40}$

The growth of public interest litigation led in turn to the growth of public interest law offices dedicated to litigating such cases. The United States has a vigorous network of public interest, nonprofit litigation offices, funded by tax deductible donations, that can litigate cases without fee. ${ }^{41}$ In addition, the U.S. bar has a tradition of pro bono representation offered by private law firms. Almost all of the early human rights cases were litigated by non-profit law offices, with occasional pro bono assistance from private firms.

U.S. commentators have explained at length the benefits that civil litigation offers to the victim, to the human rights movement, and to societyeven litigation that does not result in actual payment of the damages awarded. ${ }^{42}$ Where the legal theories are novel or untested, a civil lawsuit may

37. Harold Hongju Koh, Transnational Public Law Litigation, 100 YALE L.J. 2347, 2366

38. Abram Chayes, The Role of the Judge in Public Law Litigation, 89 HARV. L. REv. 1281, 1284 (1976).

39. Id at 1302

40. Id. at 1292-93.

41. One explanation for the rise of public interest law firms in the United States is that such offices respond to particular characteristics of the U.S. legal profession:

While in theory all lawyers are expected to contribute to the "public interest," in fact this universal obligation conflicts with the ideal of the zealous advocate and is inconsistent with the "do everything for the client at all costs" mentality of the corporate firms. As a result, we have seen in the American legal field the creation of "public interest" advocates who specialize in representing the unrepresented, and thus discharge the profession's moral obligation for all. Public interest advocates function as a necessary "corrective" in an adversarial system where not all interests are organized or represented .... As the large corporate law firm became increasingly identified with its powerful clients, a need emerged for mechanisms and institutions to ensure justice for those who could not afford the elite, specialized and costly services offered by such firms. ... The uniquely American institution of the public interest law firm, therefore, is a response to the growing size, power, and client identification of the corporate mega-law firm, as well as the embodiment of a belief in social change through law.

David M. Trubek, et al., Global Restructuring and the Law: Studies of the Internationalization of Legal Fields and the Creation of Transnational Arenas, 44 CASE W. RES. L. REV. 407, 458-60 (1994).

42. See STEPHENS \& RATNER, supra note 3, at 233-38 (explaining the value of civil remedies), 
seek first to obtain a judicial recognition of the rule of law, a precedent that can then be used to influence future policies and as a basis for future litigation. In addition, civil litigation may lead to a full investigation of the facts of an incident, identify the persons responsible, produce a public judgment of that responsibility, and generate compensation for those harmed and punitive damages as a sanction for the accused. Even absent payment of a judgment, the defendant may be "punished" by public exposure, as well as by legal consequences such as immigration penalties. ${ }^{43}$ Although not a substitute for criminal prosecutions as a means of punishment, civil remedies complement such prosecutions where they are possible, and serve an important role where criminal prosecution is not an option.

This trend of public interest litigation predisposes the U.S. public, judiciary, and legal advocates to view civil litigation as a potential means to realize large-scale policy goals and hold accountable perpetrators of egregious abuses, whether or not such litigation results in an enforceable judgment. Human rights civil litigation fits neatly within the U.S. conception of the role of the legal system and the civil lawsuit.

\section{Systematic Procedural Advantages}

In addition to a legal and popular culture that favors civil litigation as a means of influencing public policy, human rights litigation is aided in the United States by a series of favorable rules of civil procedure. Several legal practices promote civil litigation in general and public interest litigation in particular. Although not intended to be exhaustive, the following list offers an overview of some of the most important. ${ }^{44}$

No Penalty for Losing: Perhaps most important, we do not follow the "loser pays" system, under which the losing party is required to pay the legal fees of the victorious opponent. Thus, there are no penalties for bringing a lawsuit that is unlikely to succeed, as long as it satisfies the minimal requirements of professional responsibility and the rules of civil procedure. ${ }^{45}$

234 ("[T]he plaintiffs in these cases are concerned about much more than money. They take tremendous personal satisfaction from filing a lawsuit, forcing the defendant to answer in court or to abandon the United States, and creating an official record of the human rights abuses inflicted on them or their families."); Jose E. Alvarez, Rush to Closure: Lessons of the Tadic Judgment, 96 MiCH. L. REV. 2031, 2101-04 (1998) (explaining the value of civil remedies); Beth Stephens, Conceptualizing Violence Under International Law: Do Tort Remedies Fit the Crime?, 60 ALB. L. REV. 579, $603-05$ (1997) (same).

43. Hector Gramajo lost his visa for the United States after a judgment against him in Xuncexx v. Gramajo. Reuters, Guatemalan Ex-Army General Barred from United States, Sept. 13, 1995.

44. Note that where rules are considered "procedural" they are applied whether or not the substantive law of another forum governs the claim. In areas deemed "substantive," the courts may choose to apply the laws of another forum, usually the forum where the claim arose, or the rules of

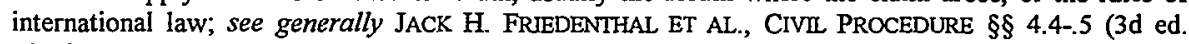
1999).

45. Rule 11(b) of the Federal Rules of Civil Procedure requires that an attorney submitting a claim to the court certify that, "to the best of that person's knowledge, information, and belief, formed after an inquiry reasonable under the circumstances," the claim is "warranted by existing law or by a nonfrivolous argument" for the modification of that law, Fed. R. Civ. P. 11(b)(2), and that all factual contentions "have evidentiary support" or are "likely to have evidentiary support" after further 
Contingency Fees: The contingency fee arrangement tempts even private, for-profit law firms to participate in public interest cases that may lead to large, collectable judgments. Predictably, the private bar has litigated human rights cases over the past few years against governments and corporations, categories of defendants who are more likely to satisfy judgments than the individual perpetrators sued in the early rounds of litigation. ${ }^{46}$

Punitive Damages: The possibility of an award of punitive damages renders civil litigation of greater interest in the United States for two reasons. First, it increases the awards, creating the potential for a judgment many times higher than one limited to compensation, which is of interest to plaintiffs and attorneys where collection of the award is considered a possibility. Second, the mere fact that punitive damages are awarded transforms the judgment into one that punishes defendants, expressing society's revulsion for their conduct and transforming the action into one that shares certain attributes with a criminal prosecution. "[P]unitive damages advance the interests of punishment and deterrence, which are also among the interests advanced by the criminal law ....."47

Default Judgments: In the U.S. system, default judgments can be rendered against a defendant over whom the court has obtained personal jurisdiction. As a result, if a defendant is served process while temporarily in the forum, then leaves immediately, the case can proceed to judgment even in the defendant's absence. Most of the early human rights cases resulted in default judgments.

Discovery: Broad U.S. discovery rules enable plaintiffs to prove their cases through documents and other information obtained from defendants. ${ }^{48} \mathrm{~A}$ civil case can be filed based upon a reasonable belief in the allegations of the complaint, with the expectation that proof sufficient to convince a jury can be obtained in the course of discovery. ${ }^{49}$ This ability to turn the defendant's files and other information into evidence to prove the plaintiff's case makes it far

investigation, Fed. R. Civ. P. 11(b)(3).

46. Cases in which plaintiffs are represented by private attorneys include several filed against foreign governments under the "terrorist state" exception to the Foreign Sovereign Immunities Act. See discussion, supra notes 26-30. See also Hilao v. Estate of Marcos, 103 F.3d 789 (9th Cir. 1996) (class action against the Estate of Ferdinand Marcos, in which Swiss bank accounts belonging to the exdictator were frozen at the onset of the litigation). Some private firms also take human rights cases pro bono, of course, with no expectation of collecting fees.

47. Browning-Ferris Industries of Vermont, Inc. v. Kelco Disposal, Inc., 492 U.S. 257, 275 (1989). "The Court's cases abound with the recognition of the penal nature of punitive damages." Id. at 297 (O'Connor, J., dissenting). As the court said in Beckwith v. Bean, 98 U.S. (8 Otto) 266, 277 (1878), "The principle of permitting damages, in certain cases, to go beyond naked compensation, is for example, and the punishment of the guilty party for the wicked, compt, and malignant motive and design which prompted him to the wrongful act."

48. See Fed. R. Civ. P. 26 (setting forth scope of permissible discovery in federal litigation).

49. For a summary of Rule 11 of the Federal Rules of Civil Procedure, see supra note 45 . In addition, the federal rules require only a "short and plain statement of the claim showing that the pleader is entitled to relief," Fed. R. Civ. P. 8(a), allowing a case to proceed based upon skeletal allegations of the key facts. 
easier to file cases where the bulk of the information is in the control of the defendant.

All of these factors - a legal tradition of impact litigation, the structure of attorneys' fees and the availability of public interest litigators, default judgments, and discovery - combine to render civil litigation in U.S. federal courts an attractive option for public interest litigators, as well as their private, fee-oriented colleagues. Combined with favorable jurisdictional rules that enable suit against individuals transitorily in the country or corporations doing business in the United States, the U.S. legal system offers a uniquely supportive framework for civil lawsuits seeking damages for international human rights abuses.

I have focused here on identifying these litigation-friendly procedures, while avoiding the heated debate about the wisdom of a legal system that encourages litigation. It is important to stress, however, that these incentives are not unique to human rights litigation, but rather apply to all civil litigation. ${ }^{50}$ And, even those who generally criticize our overly litigious society might recognize that the United States performs an important service by permitting small numbers of foreign plaintiffs access to the U.S. legal system to seek redress that is unavailable to them in their home countries. ${ }^{5}$

The numbers are small because despite the favorable procedures, the obstacles to such cases remain daunting. In very few cases can a plaintiff who has suffered a gross human rights violation be linked with a defendant who is subject to suit in the United States and with lawyers who have the time and resources to litigate such a complicated claim. Even when all of these pieces fall into place, many victims choose not to pursue the legal process. ${ }^{52}$ Moreover, many cases filed under the ATCA have been dismissed for problems ranging from the inability to prove the underlying claims to immunities to failure to state a violation of the law of nations. ${ }^{53}$ Nevertheless,

50. International human rights cases represent a tiny fraction of the federal court caseload. As stated by Chief Judge Walker of the Second Circuit: "It is safe to say that, quantitatively, international human rights law is not a major, or even a minor, component of the business of federal courts: it is a minuscule part of what we do . . . "Hon. John M. Walker, Jr., Domestic Adjudication of International Human Rights Violations Under the Alien Tort Statute, 41 ST. Lovis U. L.J. 539, 539 (1997).

51. Michael Bazyler has praised the U.S. legal system for its unique capacity to resolve claims arising out of the Holocaust:

The filing of such suits at the close of the twentieth century presents the last opportunity for the elderly survivors of the Holocaust to have their grievances heard in a court of law. ... [A]s with almost all transnational litigation, the highly-developed and expansive system of justice in this country suggests that the United States remains the best forum for the disposition of such claims. It is a tribute to the U.S. system of justice that our courts can handle claims that originated over fifty years ago in another part of the world.

Michael J. Bazyler, Nuremberg in America: Litigating the Holocaust in United States Courts, 34 U. RICH. L. REV. 1, 8 (2000) (footnotes omitted).

52. As an attorney with the Center for Constitutional Rights from 1990-1995, I regularly received phone calls and letters from individuals interested in filing human rights lawsuits. The vast majority never resulted in litigation because of one or more of the following problems: no violation of internationally protected human rights, no plaintiff willing to come forward, no defendant subject to suit, or no attomey available to undertake the effort.

53. See, e.g., Beanal v. Freeport-McMoran, Inc., 197 F.3d 161 (5th Cir. 1999) (dismissing suit because of failure to allege facts sufficient to support claims); Hamid v. Price Waterhouse, 51 F.3d 1411, 1417-18 (9th Cir. 1994) (finding that claims of fraud, breach of fiduciary duty, and 
the excitement and interest generated by these cases among human rights activists and scholars reflects the impact they have had on human rights advocacy in the United States.

\section{A COMPARATIVE ANALYSIS: Why FILARTIGA DOES NOT TRANSLATE LITERALLY}

The Filártiga decision and the cases that followed attracted virtually no interest outside of the United States until the mid 1990s, when several developments sparked increased attention in Europe. In 1993, a human rights case filed in U.S. federal court against Radovan Karadzic, the leader of the Bosnian Serbs, sought to apply the doctrine to abuses committed in Europe, in a human rights setting where innovative approaches to accountability seemed urgent. $^{54}$ At the same time, a Filártiga-style civil lawsuit, Al-Adsani v. Kuwait, was filed in England. ${ }^{55}$ Al-Adsani, a Kuwaiti who had been badly tortured in Kuwait, sought damages from both the government of Kuwait and three individuals responsible for his torture. ${ }^{56}$ Later in the 1990 s, several cases targeting corporate defendants drew increasing interest in Europe, including Wiwa v. Royal Dutch Petroleum Co., a case filed against two European-based companies. ${ }^{57}$ A motion to dismiss for forum non conveniens in Wiwa forced both plaintiffs and defendants to debate the possibility of bringing suit in either England or the Netherlands. ${ }^{58}$

Despite this increased interest, no core Filártiga-style lawsuits were filed outside of the United States. Instead, efforts to hold accountable those responsible for egregious abuses in the former Yugoslavia and elsewhere have focused on criminal prosecutions. The absence of core Filártiga cases can

misappropriation of funds are not breaches of the "law of nations" for purposes of jurisdiction under the Alien Tort Statute); Lafontant v. Aristide, 844 F. Supp. 128 (E.D.N.Y. 1994) (dismissing suit because of head-of-state immunity).

54. First filed in 1993, the case was dismissed by the district court in 1994 and reinstated on appeal in 1995. Kadic v. Karadzic, 70 F.3d 232 (2d Cir. 1995). When the case was filed in February 1993, the International Criminal Tribunal for the Former Yugoslavia was just getting underway, the war was still raging in Bosnia, and refugees were flooding Europe, bringing with them accounts of horrific human rights abuses. A $\$ 4.5$ billion judgment was entered against Karadzic in September 2000. David Rhode, Jury in New York Orders Bosnian Serb to Pay Billions, N.Y. TIMES, Sept. 26, 2000, at Al0.

55. The facts and legal history of the case are summarized in Al-Adsani v. Government of Kuwait, 107 I.L.R. 536, 538-39 (Eng. C.A. 1996).

56. The case differed from "core" Filarrtiga cases (i.e., independent civil lawsuits against nonresident defendants for international human rights abuses committed outside of the forum state) in that the plaintiff alleged that he had been injured in England by threats that caused him mental harm, as well as having been tortured in Kuwait. Id at 536, 539 .

57. 226 F.3d 88 (2d Cir. 2000), cert. denied, 121 S. Ct. 1402 (2001) (reversing the dismissal of claims of torture and summary execution against a multinational corporation, in a case filed by family members of the deceased victims and survivors of human rights violations in Nigeria); see also Doe v. Unocal, 963 F. Supp. 880 (C.D. Cal. 1997) (holding that a U.S. corporation could be held liable for forced labor used in its joint venture project with the Burmese government). Doe v. Unocal was later dismissed on a motion for summary judgment, 110 F. Supp. 2 d 1294 (C.D. Cal. 2000), a decision which is currently on appeal.

58. The District Court dismissed, finding that England was a more appropriate forum, but the Second Circuit reversed the dismissal, concluding that defendants had not met their burden of showing that England was a more convenient forum for these human rights claims. Wiwa, 226 F.3d at 99-108. 
only be understood by examining some of the ways in which the procedural rules governing civil litigation in disparate legal systems differ markedly from those in the United States. Although the differences between the common law U.S. system and civil law systems are particularly pronounced, difficult translation problems exist even among the largely similar common law systems. These problems occur even in England, the system most similar to the United States. Indeed, despite a great deal of interest in the Filártiga doctrine in England, a British international law study group recently concluded that the likelihood of such litigation in Britain was slim. ${ }^{59}$ This result is not a product of different views of international law. Instead, it is the result of domestic laws that differ in small but crucial details and render such litigation unlikely to succeed and financially risky. It also reflects sharply different attitudes toward civil litigation as a tool of legal reform.

My goal in this Part is to explore the legal and cultural differences that help explain why there have been no core Filártiga cases outside of the United States. I first discuss the varied ways in which different legal systems define the relationship between criminal prosecutions and civil claims. Given that human rights violations involve conduct that almost always constitutes a crime, systems that link civil and criminal procedures often either limit the availability of an independent civil claim, or render such claims less important. Civil claims are also deterred in many systems by jurisdictional requirements, cultural attitudes toward litigation, and procedural obstacles, which I review in the final Sections of this Part. These differences in procedures and attitudes have stymied interest in pursuing core Filártiga actions, at the same time that the broad Filártiga commitment to accountability has spread rapidly around the globe.

\section{A. Civil/Criminal Links}

Where conduct constitutes both a crime and a tort, the U.S. system allows both actions to proceed independently; the fact that a criminal prosecution is initiated and results in either an acquittal or a conviction does not bar a subsequent civil action. ${ }^{60}$ In many legal systems, however, the two possible legal actions arising out of one set of facts are viewed as interdependent, with many variations on how this relationship is implemented. ${ }^{61}$ Since human rights violations generally constitute crimes, limitations of this type sharply impact the possibility of civil claims for such abuses.

59. BRITISH ILA REPORT, supra note 5, at 165-66.

60. At the defendant's request, the civil proceedings are likely to be postponed pending resolution of the criminal charges. If the defendant is convicted, the finding of guilt will generally lead to a holding of civil responsibility as well. If a defendant is acquitted, however, the civil action can still proceed; since the standard of proof is lower in a civil case, the plaintiff may be able to show civil liability even though the proof was not sufficient to prove criminal guilt.

61. See generally J. A. Jolowicz, Procedural Questions, in 11 INTERNATIONAL ENCYCLOPEDIA OF COMPARATIVE LAW, ch. 13, at 5-11 (Andre Tunc ed., 1986) (describing the interdependence of civil and criminal actions in many legal systems). 
Many civil law systems permit civil claims to be filed as an adjunct to a criminal prosecution. ${ }^{62}$ In France, for example, the victim of a crime can join the criminal prosecution as a partie civile, becoming a party to the case with the right to access to the proceedings, to seek compensation for the harm caused, and to appeal an adverse decision. ${ }^{63}$ In Spain, compensation to the victim is automatically part of a criminal prosecution. ${ }^{64}$ Another variation permits private parties to initiate criminal proceedings, either by filing a formal request asking the public prosecutor to file charges or by pursuing an action as a private prosecutor. The case against Pinochet in Spain, for example, began when a private organization filed a criminal complaint against members of the Argentine military, which subsequently expanded to include charges against Pinochet. ${ }^{65}$ Civil claims can then be attached to these privately initiated prosecutions. ${ }^{66}$

Such procedures provide both advantages and disadvantages to the victim of a human rights abuse who seeks civil remedies. Where the system works smoothly, the private party is able to take advantage of the public prosecutor's investigation and presentation of the case, avoiding the costs of litigation. Under such a legal regime, there would be little reason for victims and their advocates to develop an independent system of civil remedies for human rights abuses. In France, for example, joining a civil claim to a criminal prosecution is apparently a very effective, widely used mechanism. ${ }^{67}$ "Translation" thus requires understanding that in some countries, civil claims attached to criminal prosecutions may play the same role as independent civil lawsuits in the United States.

In other situations, however, the interconnected criminal and civil procedures may in fact block access to redress. For example, in many such systems, once a criminal charge has been filed, no civil claim can be brought until the criminal proceedings have been resolved. Thus even if a civil claim might otherwise be possible, it is blocked by the filing of a criminal prosecution, even if the criminal proceeding stalls and no actual prosecution is likely ${ }^{68}$ In Guatemala, for example, the opening of a sham criminal

62. Id. Countries following this system include, for example, Austria, Egypt, France, Italy, Mexico, Poland, Romania, Spain, Sweden, and Venezuela. Id. at 5; see also Beth Van Schaack, In Defense of Civil Redress: The Domestic Enforcement of Human Rights Norms in the Context of the Proposed Hague Judgments Convention, 42 HARV. INT'L L.J. 141, 145-147 (2001).

63. Jolowicz, supra note 61, at 5; see generally Matti Joutsen, Listening to the Victim: The Victim's Role in European Criminal Justice Systems, 34 WAYNE L. REV. 95, 115-18 (1987) (describing partie civile system in effect in many European legal systems); Jean Larguier, The Civil Action for Damages in French Criminal Procedure, 39 TUL. L. REV. 687 (1965) (same).

64. Van Schaack, supra note 62, at 145 n.18; Codigo Penal [C.P.], arts. 109-100 (Spain); Ley De Enjuiciamiento Criminal [L.E.CRIM], art. 100 (Spain).

65. Naomi Roht-Arriaza, The Pinochet Precedent and Universal Jurisdiction, 35 NEW ENG. L. REV. 311, 311-12 (2001).

66. See Richard S. Frase, Comparative Criminal Justice as a Guide to American Law Reform: How Do the French Do It, How Can We Find Out, and Why Should We Care?, 78 CALIF. L. REV. 539, 613 n.400, 669-70 (1990) (describing the French system of privately initiated prosecutions); Joutsen, supra note 63, at 110-14 (comparing private prosecution in several European systems).

67. According to one study, twenty percent of all criminal prosecutions included attached civil claims. Frase, supra note 66 , at 613 n.400.

68. Jolowicz, supra note 61 , at $5 \mathrm{n.12}$ (" $[1] \mathrm{f}$ criminal proceedings have begun against the 
investigation into allegations by Sister Dianna Ortiz prevented Ortiz from taking any legal action on her own behalf, although the criminal investigation was effectively shelved by the authorities. ${ }^{69}$ Moreover, in such systems, the outcome in the criminal case is often binding on the civil claim: a criminal acquittal cuts off the possibility of a damage award. ${ }^{70}$

In other systems, the reality is less advantageous than it appears on paper: awards may be limited to symbolic, rather than compensatory, damages. In the Netherlands, for example, the maximum damages available through the criminal system is approximately $\$ 600 .^{71}$ Indeed, in the only recorded civil damage award in a European human rights case, where the civil claim was joined to the criminal prosecution, the victim received a symbolic award of one franc, plus costs. ${ }^{72}$ In general, "compensation awarded in cases relating to violations of human rights or humanitarian law is usually regarded as symbolic."73

In addition, criminal prosecutions usually depend upon a decision by the public prosecutor to file charges; plaintiffs may be unable to convince the government authorities to act. The option of filing private prosecutions may respond to this problem, but only if the risks to the private plaintiff are minimized. Indeed, the utility of such actions can only be determined by reading and understanding the fine print. For example, in France, a private party who brings an unsuccessful criminal prosecution is liable to the defendant for the costs of the defense; as a result, very few such prosecutions actually occur. $^{74}$

Finally, even in systems where civil and criminal proceedings are independent, the government's failure to prosecute may make a civil claim impossible where essential information is inaccessible to private litigants. Thus, the Inter-American Commission on Human Rights held recently that the Chilean government violated the right to civil remedies by blocking criminal prosecution. ${ }^{75}$ The case involved the 1974 disappearance of an agricultural technician with ties to the Communist Party. The Chilean courts had ruled that

accused, the action before the civil court must be stayed until after final judgment in the criminal proceedings."). See, e.g., Ley De Enjuiciamiento Criminal [L.E.CRIM], art. 100 (Spain).

69. Xuncax v. Gramajo, 886 F.Supp. 162, 178 (D. Mass. 1995) (finding that Ortiz, a U.S. nun who was kidnaped and brutally tortured while working in Guatemala, had no effective civil remedy available to her in Guatemala). Similar rules blocked civil action by the Filártiga plaintiffs in Paraguay. Filártiga v. Pena-Irala, 630 F.2d 876, 879 n.5 (2d Cir. 1980).

70. Jolowicz, supra note 61, at 31; Larguier, supra note 63, at 699 (stating that in France, "as a rule, civil judges are obliged to follow the decision of the criminal court.").

71. See Consideration of Reports Submitted by State Parties Under Article 19 of the Convention (The Netherlands), Committee Against Torture, U.N. Doc. CAT/C/9/Add. 1, at 31 (Mar. 20 1990).

72. REDRESS, UNIVERSAL JURISDICTION IN EUROPE: CRIMINAL PROSECUTIONS IN EUROPE SINCE 1990 FOR WAR CRIMES, CRIMES AGANNST HUMANITY, TORTURE AND GENOCIDE 14 (1999). This is the only case surveyed in the comprehensive Redress report in which a civil claim was attached to the criminal prosecution.

73. Id.

74. Frase, supra note 66 , at 613 n.400, 669-670, 670 n.654.

75. IACHR, Report No 61/01 (Case 11.771, Samuel Alfonso Catalán Lincoleo v. Chile) (Apr. 16, 2001), available at http://www.cidh.oas.org/annualrep/2000eng/chapteriii/merits/chile1 1.771.htm. 
an amnesty statute prevented a criminal prosecution. ${ }^{76}$ Although Chilean law in theory permitted civil litigation to proceed in the absence of such prosecution, the Commission found that the government's failure to investigate made it practically impossible to identify those responsible for the disappearance:

[T] he civil claim must be lodged against a specific person in order to establish their responsibility for the alleged acts and determine the payment of compensation. The absence of an investigation by the State made it materially impossible to establish responsibility through the civil courts. Even though the Supreme Court of Chile has affirmed the fact that civil and criminal proceedings are independent, the manner in which the amnesty was applied by the courts affected the right to obtain reparations through the civil courts, because it was impossible to individualize or identify those responsible for the disappearance, torture, and extrajudicial killing of Samuel Alfonso Catalán Lincoleo. 7

Thus, the practical reality of the need for a government investigationparticularly acute in systems where discovery is non-existent or limited, as discussed in the following Section-may make it impossible to file civil claims in the absence of a criminal prosecution.

To summarize, in some legal systems, the ability to initiate criminal prosecutions or to attach civil actions to those prosecutions may provide an attractive means by which to obtain redress for human rights violations; such actions should be considered virtually equivalent "translations" of Filártigastyle civil lawsuits. In this situation, the question, "why have there been no Filartiga lawsuits in X jurisdiction" is misguided: there have been such lawsuits, but in forms appropriate to disparate domestic legal systems. In other systems, however, the procedural barriers created by the linkage between criminal and civil claims, and the difficulties inherent in utilizing the joint procedures, may in practice work to impede access to redress. Under this situation, the same question is answered differently: there have been no Filártiga-style civil lawsuits because local procedures make them difficult or impossible.

\section{B. Barriers to Independent Civil Litigation}

Domestic legal systems inevitably develop legal practices that are a product of local procedures and local attitudes. Even where systems appear to be substantially similar, these differences can amount to wide variations in the practical possibilities of litigating complex claims such as those based upon international human rights violations. Problems arise at almost every stage, including jurisdiction, choice of law, and litigation procedures. Moreover, differences in attitudes toward the court system and civil claims lead to dramatically opposed conclusions about the wisdom of such litigation.

76. As the Inter-American Human Rights Court stated in this decision, "It is important to note that in many of Latin America's criminal justice systems the victim has the right to file charges in criminal proceedings. Such is the case in Chile, where the victim of a crime has a fundamental right to recourse before the courts as a party in the criminal proceedings ...." Id. I 61 .

77. Id. Tf 63-65. 


\title{
1. Limits on Extraterritorial Jurisdiction
}

The broadly defined Filártiga doctrine encompasses all civil litigation for international human rights violations, including suits against local defendants for abuses committed locally. Several Filártiga cases have been filed against U.S. defendants, including individuals domiciled in the United States, local or federal governments, and corporations incorporated in the United States, for abuses committed in this country or abroad. ${ }^{78}$ Where the defendant is local, human rights claims fit within standard jurisdictional principles common to legal systems around the world.

\begin{abstract}
Actor sequitur forum rei is the fundamental principle accepted virtually everywhere. Plaintiff follows the defendant to the latter's forum, i.e., to the defendant's domicile. . . [T] he defendant's domicile seems to be the only place where no one asks, in an inquiry directed to jurisdiction, what the claim or cause of action is about. . . . In short, judicial jurisdiction on the basis of the defendant's domicile-or for a corporation its principal place of business-is general jurisdiction. ...
\end{abstract}

General jurisdiction over local defendants permits assertion of any claim against those defendants, including claims arising out of human rights violations committed in another country. At the same time, virtually all legal systems assert jurisdiction over claims arising out of activities committed locally (i.e., specific jurisdiction). Thus human rights claims arising out of violations committed within the nation's territory would not raise jurisdictional problems either.

Core Filártiga cases, however, assert claims against foreign defendants for violations committed in a foreign country. In the United States, as explained in the previous section, such claims are possible because jurisdiction can be asserted over individuals temporarily present in the country or over corporations "doing business" in the United States. These categories of jurisdiction, however, are common only in the Anglo-American tradition. ${ }^{80}$ Indeed, jurisdiction based on "transitory" presence has been widely criticized around the world, and has been expressly rejected by the only international jurisdictional treaty, the Brussels Convention regulating jurisdiction in

78. See, e.g., Harbury v. Deutch, 233 F.3d 596, 600 (D.C. Cir. 2000) (U.S. government officials); Martinez v. Los Angeles, 141 F.3d 1373 (9th Cir. 1998) (local government officials); AbebeJira v. Negewo, 72 F.3d 844 (11th Cir. 1996), cert. denied, 519 U.S. 830 (1996) (U.S. resident); Jama v. INS, 22 F.Supp. 2d 353 (D. N.J. 1998) (U.S. officials and U.S. corporation); Doe v. Unocal, 963 F. Supp. 880 (C.D. Cal. 1997) (U.S. corporation).

79. Andreas F. Lowenfeld, International Litigation and the Quest for Reasonableness, 245 R.C.A.D.I. 9, 81 (1994). See also Hans Smit, Common and Civil Law Rules of In Personam Adjudication Authority: An Analysis of Underlying Policies, 21 INT'L \& COMP. L.Q. 335, 336 (1972) ("The notion that the plaintiff should sue the defendant at his home is of venerable age, and the rule permitting him to be sued there is universally accepted. However, as commerce, transportation, and communications have grown, the pressure towards additional fora have become steadily greater.").

80. Japan, however, would also permit the assertion of general jurisdiction over a defendant with a place of business in the forum if the assertion complied with "'jori' . . . the principle of reasonableness and fairness," which "realizes fairness between the parties, adequacy of judgment, and promptness of trial." See Lowenfeld, supra note 79, at 87 (quoting the Supreme Court of Japan, Oct. 16, 1981). 
Europe. ${ }^{81}$ General jurisdiction under the Convention is available in the defendant's country of domicile, ${ }^{82}$ while specific jurisdiction is available for torts in the "place of harm," either the place where the tortious act occurred or the place where injury resulted. ${ }^{83}$ In addition, jurisdiction may be exercised over all co-defendants and third-party defendants, even where those parties have no connection to the forum. ${ }^{84}$

Many countries, in Europe and elsewhere, assert jurisdiction in some situations that go beyond this core. The Brussels Convention does not require that participating states eliminate all non-Convention bases of jurisdiction. Rather, it labels such practices as "exorbitant" jurisdiction, and bars them in litigation among domiciliaries of member states. ${ }^{85}$ Each is free to rely on such grounds in litigation with domiciliaries of non-members. ${ }^{86}$ The prohibited list includes jurisdiction based on transitory physical presence, permitted in England and Ireland; ${ }^{87}$ ownership of property within the forum which is not the basis of the litigation, permitted in Sweden $;^{88}$ and the nationality of the plaintiff or defendant, permitted in France. ${ }^{89}$ Many European countries also have reciprocity or retaliatory rules: they will assert jurisdiction over a

81. Convention on Jurisdiction and the Enforcement of Judgments in Civil and Commercial Matters, done at Brussels, Belgium, Sept. 27, 1968, as amended, 1990 O.J. (C 189) 1, reprinted in 29 I.L.M. 1413 (1990) [hereinafter Brussels Convention]. The Brussels Convention is in effect for the twelve countries that were members of the European Community (European Union) prior to January 1 , 1995 (Belgium, Netherlands, Luxembourg, United Kingdom, France, Germany, Italy, Greece, Spain, Portugal, Ireland, and Denmark), while six additional countries are bound to the same system by the Lugano Convention (Austria, Finland, Iceland, Norway, Sweden, and Switzerland). Convention on Jurisdiction and Enforcement of Judgments in Civil and Commercial Matters, done at Lugano, Italy, Sept. 16, 1988, 1988 O.J. (L 319) 9, reprinted in 28 I.L.M. 620 (1989).

82. Brussels Convention, supra note 81 , art. 2. Domicile of an individual is determined by the forum law, with minor variations from country to country. Id. art. 52(1) (forum applies local law to determine domicile of party). The domicile of a corporation is defined by the Convention as its "seat." Id. art. 53; see also Brian Pearce, The Comity Doctrine as a Barrier to Judicial Jurisdiction: A U.S.-E.U. Comparison, 30 STAN. J. INT'L L. 525, 534 (1994) (explaining that European legal systems apply different standards to determine the corporate "seat," defining it as the center of managerial control, the location of the corporation's "principle establishment," or the place of incorporation).

83. Brussels Convention, supra note 81, art. 5(3); see also Silberman, supra note 34, at 400 401; Pearce, supra note 82 , at 535 n.51.

84. Brussels Convention, supra note 81 , arts. $6(1), 6(2)$.

85. Id. art. 3.

86. Id. arts. 3,4 .

87. Id.

88. Known at the "Swedish umbrella rule," this rule permits general jurisdiction over an individual who has left a piece of property in the forum country, no matter how minimal its value. Pearce, supra note 82, at 542. "The danger of leaving one's umbrella in Sweden is known the world over. For if a non-resident leaves his umbrella in Sweden, he creates the authority for a Swedish court to cast him in a personal judgment for a debt obligation in any amount." Smit, supra note 79, at 335. In recognition of international criticism, Germany narrowed its similar rule to cases in which "the cause of action had some link to the forum." Lowenfeld, supra note 79, at 98-99 (citing M. v. T., 115 BGHZ 90, Bundesgerichtshof 2 July 1991). See Gerhard Dannemann, Jurisdiction Based on the Presence of Assets in Germany: A Case Note, 41 INT'L \& COMP. L.Q. 632 (1992).

89. Articles 14 and 15 of the French Civil Code assert French jurisdiction over any suit brought by a French national or brought against a French national. Versions of the "nationality" rule are followed in the Netherlands, Luxembourg, Rumania, Haiti, and Quebec. See Michael Akehurst, Jurisdiction in International Law, 1972-73 BRIT. Y.B. INT'L L. 145, 172-73; Born, supra note 33, at 14; F.A. Mann, The Doctrine of Jurisdiction in International Law, 113 R.C.A.D.I. 1, 39 (1964); Pearce, supra note 82, at 539 . 
foreigner if his or her country would assert jurisdiction in the same situation. ${ }^{90}$ Where such jurisdictional principles are permitted, human rights claims might be possible based on temporary presence, property, or nationality.

Nevertheless, setting aside these "exorbitant" bases for jurisdiction, standard principles of jurisdiction will only permit jurisdiction over foreign actors for domestic violations, or over domestic actors for abuses committed in foreign countries, whether those actors be individuals or corporations. ${ }^{11}$ Core Filártiga cases, however, require the assertion of jurisdiction over foreign actors for abuses committed in foreign countries, a situation not contemplated by the most common jurisdictional principles. ${ }^{92}$ These restrictions by themselves make core human rights lawsuits impossible in many legal systems. In addition, even where jurisdictionally possible, procedural rules and cultural attitudes toward civil litigation may render such claims difficult or disfavored in many legal systems.

\section{Resistance to Litigation as a Tool of Policy Reform}

Civil human rights litigation in the United States is the natural product of a legal culture that relies on private lawsuits both as a means to obtain compensation for injuries and also as a tool to address societal problems. One result is a high rate of civil litigation. This is confirmed by statistics showing a litigation rate higher than that in many other societies. ${ }^{93}$ Although the data is difficult to collate and compare, ${ }^{94}$ it seems noncontroversial to conclude that the United States is among the countries with the highest rate of recourse to the courts to resolve disputes. These differences reflect in part a propensity in the United States to turn to the courts rather than to other dispute resolution mechanisms as a means to resolve grievances. At the other extreme, Japan and

90. Born, supra note 33, at 15 ; Pearce, supra note 82, at 540 .

91. English courts held that the allegation that threats made against Al-Adsani in England caused injury in England served as a basis for asserting personal jurisdiction over the alleged tortfeasors. Al-Adsani v. Government of Kuwait, 107 I.L.R. 536, 538-39 (Eng. C.A. 1996).

92. The impact of international rules providing for universal jurisdiction over claims of certain egregious violations is discussed in Part IV.

93. Merryman offers data from the 1980 s indicating comparative civil litigation rates:

Civil Cases Filed Per 100,000 Population

France (1987) 2,412

Germany (1984) $\quad 3,756$

Italy (1987) $\quad 1,630$

Japan (1985) $\quad 680$

U.S. (1989) $\quad 5,968$

JOHN H. MERRYMAN ET AL., THE CIVIL LAW TRADITION: EUROPE, LATIN AMERICA, AND EAST ASIA 599, 643 (1994). A comparison of litigation rates in several civil law countries, however, showed both Austria and Belgium approaching the U.S. rate, with 5,020 cases per 100,000 in Austria and 4,800 per 100,000 in Belgium. Erhard Blankenburg, Civil Litigation Rates as Indicators for Legal Cultures, in COMPARING Legal CUlTURES 41, 46 (David Nelken ed., 1997). Note that by 1992 the U.S. rate was reportedly up to 6,610. Susanne Di Pietro \& Teresa W. Carns, Alaska's English Rule: Attorney's Fee Shifting in Civil Cases, 13 ALASKA L. REV. 33, 63 (1996).

94. Merryman points out that "[c]ross-national comparisons confront serious methodological difficulties." Supra note 93, at 599. Blankenburg, supra note 93, also discusses the difficulties of comparing litigation rates in different countries. 
other East Asian societies exhibit a greater tendency to mediate disputes than to resolve them through litigation. ${ }^{95}$

Lower rates of litigation may also reflect a different role for the judiciary. In Latin America, the judicial system still reflects its roots in a hierarchical and bureaucratic colonial past. "The judicial system ... was not really conceived as an institution to resolve the conflicts of the population at large, but rather as a component of the administration of State power, that is, as an instrument of social control."96 Despite the social upheaval of the past decades, the judiciary often remains a locus of routine bureaucratic decisionmaking in Latin America, rather than a forum for challenging the abuse of power. ${ }^{97}$

The United States has a long tradition of public interest impact litigation filed by private parties to seek recognition of problems and changes in future behavior. In many societies, resolution of such issues is seen as an obligation of government. Those who seek reform focus their efforts on pushing public officials to change policy, rather than on filing lawsuits. ${ }^{98}$ Those who see the need to hold an individual or corporation responsible for a specific abuse would be more likely to push the government to file criminal charges, rather than to litigate an independent civil claim. "The civil process is conceived in terms of private, individualistic situations," while "[t]he criminal process effectuates the public interest." ${ }^{.99}$ These basic differences about the role of the courts and private claims may affect choices about when and how to utilize the civil lawsuit. According to one observer, "a French civil suit is not merely an adversarial forum," but rather "a regulatory instrument"100 that is "geared towards the maintenance of parity between members of a society."101 As such,

95. Although commentators have proposed various explanations for the low levels of litigation in parts of Asia, it seems clear that differing attitudes toward litigation play an important part. See MERRYMAN, supra note 93, at 686-703 (debating whether East Asian societies display less "rights consciousness" than western cultures, and therefore less of a propensity to litigate disputes); Tsuneo Matsumoto, Beyond Compensation, 15 U. HAW. L. REV. 577 (1993) (discussing both cultural and structural explanations for the low level of litigation in Japan).

Sharon Hom refers to the "conventional narrative of China's legal tradition" as including a "preference for informal settlement of disputes." Hom notes, however, that recent scholarship suggests that the Chinese historically "were much more litigious and resorted to lawsuits much more frequently than has been previously understood." Sharon K. Hom, Re-positioning Human Rights Discourse on "Asian" Perspectives, 3 BUFF. J. INT'L L. 209, 217-18 n.21 (1996), citing Thomas Buoye, From Patrimony to Commodity: Changing Concepts of Land and Social Conflict in Guangdong Province During the Qianlong Reign (1736-1975), 14 LATE IMPERIAL CHINA 2 (1993); see also Tahirih Lee, Risky Business: Courts, Culture, and the Marketplace, 47 U. MIAMI L. REV. 1335 (1993).

96. Joseph R. Thome, Heading South But Looking North: Globalization and Law Reform in Latin America, 2000 Wis. L. REV. 691, 705.

97. Id. at $695,702-05$.

98. See Mauro Cappelletti, Governmental and Private Advocates for the Public Interest in Civil Litigation: A Comparative Study, 73 Mich. L. REv. 794, 878 n.380 (1975) (explaining the lesser rate of public interest litigation in civil-law systems as resulting, in part, from "a different conception of the respective roles of legislation and adjudication in the law-making process").

99. Richard B. Cappalli \& Claudio Consolo, Class Actions for Continental Europe? A Preliminary Inquiry, 6 TEMP. INT'L \& COMP. L.J. 217, 269-70 (1992).

100. Richard Azarnia, Tort Law in France: A Cultural and Comparative Overview, 13 WIs. INI'L L.J. 471, 484 (1995).

101. Id. at 488 . 
French litigants would be less likely to utilize the tort suit as a means to make a symbolic statement or as a means to punish the defendant. ${ }^{102}$

The Al-Adsani suit in England demonstrates a similar reluctance to pursue litigation for symbolic purposes. Suleiman Al-Adsani, a pilot in the Kuwaiti air force, was detained and brutally tortured by a member of the Kuwaiti royal family, and threatened with further harm after he had escaped to England. He sued three individuals and the government of Kuwait. ${ }^{103}$ The claim against Kuwait was eventually dismissed on the basis of sovereign immunity. ${ }^{104}$ Although a default judgment against one individual defendant was a possibility, Al-Adsani's attorney has stated that this option was not pursued because the defendants had no assets subject to seizure in England. ${ }^{105}$ By contrast, several U.S. lawsuits have proceeded to default judgments against absent defendants. Plaintiffs, their attorneys, and U.S. commentators have stressed the benefits of such lawsuits even where collection of the awards is unlikely. ${ }^{106}$

A further disincentive to civil litigation in many legal systems is the fact that civil remedies are purely compensatory. Punitive damages are found only in the United States and a handful of other systems. The absence of punitive damage awards accounts in part for the discomfort expressed by human rights advocates in other countries who see a civil damage award as an inadequate response to morally repugnant human rights abuses. Professor Merryman has explained the civil law system's focus on criminal prosecution-not civil damage awards - in order to punish and to express a moral judgment:

[M]orally reprehensible . . . actions are matters for the criminal law rather than for the civil law. In the civil trial, as a general rule, the plaintiff's recovery is limited to

102. Id.

103. The facts and legal history of the case are summarized in Al-Adsani v. Govermment of Kuwait, 107 I.L.R. 536, 538-39 (Eng. C.A. 1996).

104. Id. at 540-44 (Stuart-Smith, L.J.). The first Court of Appeal panel to hear the case found an exception to sovereign immunity, relying on the Filártiga doctrine for the principle that violations of international human rights norms can be litigated against any defendant, regardless of otherwise applicable immunities, a decision that was later reversed. See Al-Asdani, 107 I.L.R. at 470-71. As the subsequent panel realized, Filártiga does not address immunity or recognize an exception to sovereign immunity. Id. at 544. Moreover, in a case decided subsequent to Filártiga, the U.S. Supreme Court ruled as a matter of statutory construction that there is no general exception to the Foreign Sovereign Immunities Act for human rights violations. See discussion, supra note 21. The English court adopted a similar view in the Al-Adsani appeal, interpreting the English State Immunities Act. Al-Adsani, 107 I.L.R. at 540-44. Al-Adsani filed a claim with the European Court of Human Rights, arguing that the dismissal of his claim against the Government of Kuwait violated his right of access to courts and that his right to redress for torture, a jus cogens norm, overrode Kuwait's claim of sovereign immunity. On November 21, 2001, the Court rejected his claim by a vote of 9-8. Al-Adsani v. United Kingdom, App. 35763/97 (Eur. Ct. H.R. Nov. 21, 2001), available at http://hudoc.echr.coe.int. The majority recognized a distinction between criminal claims against individuals, such as that at issue in the Pinochet case, and civil claims against sovereign states, such as that asserted by Al-Adsani. The dissenters argued that the jus cogens nature of the prohibition against torture mandates that it take precedence over lesser norms such as that regulating sovereign immunity, regardless of whether the defendant is a sovereign state or an individual and whether the claim is civil or criminal. $I d$.

105. "Enforcement against the [sheikh], with no traceable assets outside Kuwait, would be futile. Effective redress demands that liability be established against the Kuwaiti Government.' Geoffrey Bindman, How Courts Condone Torture, THE TIMEs, Mar. 25, 1997, at 41.

106. See supra discussion accompanying notes $42-43$. 
compensation for the loss he suffered. If the judgment of the community is going to be brought to bear on a defendant because of the moral character of his action, it must be done through the processes of the criminal law .... 107

Human rights abuses are certainly among the most reprehensible violations of the law. Therefore, systems that maintain a distinction between crimes and torts based in part on whether an act is a morally reprehensible affront to the whole community, rather than only to the injured individual, would reject efforts to categorize human rights violations as torts.

Finally, the decision to employ civil litigation as a means to achieve policy reform, punishment of human rights violators, and/or redress for victims necessarily entails some level of confidence in the local judiciary. Neither victims of abuses nor their legal advocates will invest time and resources in litigation if they predict that the judiciary will let a case sit unresolved for years or dismiss it because of ill-formed legal judgments, or because of political pressure. Delays, inefficiencies, lack of independent judges, a perception of corruption, and political pressure can all lead to a culture in which civil litigation is seen as a misuse of resources that can be invested more effectively in other avenues. ${ }^{108}$

\section{Procedural Hurdles to Civil Litigation}

Different rates of litigation are also the product of procedural variations. In most legal systems, civil litigation faces hurdles that make such claims unattractive, or even unavailable, as a tool of social change. Often, such differences appear minor but have a major impact on the feasibility of pursuing civil human rights claims. Indeed, despite the similarities between the English legal system and that in the United States, such cases are unlikely to succeed in England. ${ }^{109}$

I will return several times to the Wiwa litigation in this section, as it is an example of the manner in which minor differences in roughly analogous systems combine to dramatically alter the legal landscape for core Filártiga cases. Wiwa v. Royal Dutch Shell arose out of the execution of the leaders of a movement that had challenged Shell Nigeria's business and environmental practices. ${ }^{110}$ Ken Saro-Wiwa and John Kpuinen were executed in 1995 by the Nigerian military government after a sham trial, in an effort to silence their

107. MERRYMAN, supra note 93 , at 1022.

108. See Maria Dakolias, Court Performance Around the World: A Comparative Perspective, 2 YALE H.R. \& DEV. L.J. 87 (1999) (comparing efficiency and levels of public confidence in the judiciary). Dakolias cites studies showing, for example, that only one-third of Brazilians stated that they would use the judiciary to resolve a conflict, $i d$ at 110 ; that eighty-nine percent of the public in Colombia thought that judges were open to bribes, $i d$ at 115 ; and that sixty-one percent of Ecuadorans and over seventy percent of Peruvians had no confidence in the honesty of judges, id. at 118, 130. By comparison, ninety-five percent of the public in Germany and ninety-seven percent in Singapore had confidence in the justice systems. Id. at $122,131$.

109. See British ILA Report, supra note 5, at 165-66 (concluding that the chances of pursuing civil remedies for extraterritorial human rights abuses in England were slim).

110. The facts alleged in the complaint are summarized in Wiwa y. Royal Dutch Petroletrm Co., 226 F.3d 88, 92-93 (2d Cir. 2000), cert. denied, 121 S. Ct. 1402 (2001). 
political protests. The following year their relatives filed a lawsuit in New York against Royal Dutch Petroleum Company and Shell Transport and Trading Company, the two multinational holding companies that jointly own Shell Nigeria. The complaint alleges that Shell Nigeria was complicit in the executions of Saro-Wiwa and Kpuinen. Royal Dutch is incorporated and headquartered in the Netherlands; Shell Transport is incorporated and headquartered in England.

The defendants filed several challenges to the complaint, including a motion to dismiss on the ground of forum non conveniens, arguing that the case would be more properly litigated in either England or the Netherlands. ${ }^{111}$ Under the standard enunciated by the U.S. Supreme Court, a forum non conveniens dismissal should be granted only if defendants can show, inter alia, that an adequate alternative forum exists. ${ }^{112}$ For the purposes of their motion, therefore, the Shell defendants had to show that England and/or the Netherlands would provide an alternative forum amenable to hearing the plaintiffs' claims. Both plaintiffs and defendants turned to experts to present their conflicting claims. ${ }^{13}$ The complexity of the issues raised by the expert affidavits illustrates the difficulties inherent in the effort to translate the legal practices of one country into parallel proceedings in a foreign legal system, difficulties that I explore in the following discussion.

Although this Section cannot offer a full account of the multitude of distinct legal systems around the world, I will give an overview of some of the more common legal obstacles to civil litigation for human rights abuses. These can be loosely grouped into practices that charge fees for access to the civil justice system, penalize losing plaintiffs, limit the possible recovery, restrict access to legal assistance, and make litigation itself more difficult.

Pre-paid legal fees: In many countries, the plaintiff must pre-pay the attorney a lump sum proportionate to the amount demanded in the lawsuit. In Japan, for example, a complaint seeking $\$ 1$ million would require an advance payment of $\$ 45,000$ to the attorney. ${ }^{114}$

111. Id. at 94. The possibility of litigating in the Netherlands was not fully explored by either court, for different reasons: the district court concluded that the case should be dismissed and tried in England, and therefore did not need to consider litigation in the Netherlands, while the Second Circuit decided that defendants had not made a case for dismissal even if either or both alternative fora were adequate. Id. at $94,106-08$.

The defendants' challenge to personal jurisdiction was rejected by both the district court and the Second Circuit. Id. at 94-100. The Second Circuit remanded the case to the district court for resolution of the motion to dismiss for failure to state a claim. Id. at 108 .

112. Id. at 100 (citing Gulf Oil Corp. v. Gilbert, 330 U.S. 501 (1947) and Piper Aircraft Co. v. Reyno, 454 U.S. 235 (1981)). After determining that an adequate alternative forum exists, the courts must "balance a series of factors involving the private interests of the parties in maintaining the litigation in the competing fora and any public interests at stake." Wiwa, 226 F.3d at 100 (citing Piper Aircraft, 454 U.S. at 254 n.22).

113. See Declaration of Richard Meeran (filed before Magistrate Judge Henry B. Pitman on May 5, 1998); Two Declarations of Peter Duffy (filed before Magistrate Judge Henry B. Pitman on Aug. 26, 1997 and May 5, 1998) [hereinafter Duffy I and II, respectively]; Three Declarations of Lawrence Collins (filed before Magistrate Judge Henry B. Pitman on Mar. 26, 1997, May 16, 1997, and Sept. 26, 1997) [hereinafter Collins I, II, and III, respectively].

114. Matsumoto, supra note 95 , at 578 . 
Pre-paid court fees: Some legal systems require plaintiffs to pre-pay a percentage of the amount claimed as a fee to the court. In Japan, a \$1 million demand would require paying a $\$ 5000$ filing fee; ${ }^{.15}$ in Taiwan, the fee is one percent of the amount in controversy for commercial litigation. ${ }^{116}$ In Argentina, such fees amount to three-to-seven percent of the demand. Although the plaintiff can petition the court for a waiver of the fee, the separate legal proceeding necessary to obtain a waiver is both costly and timeconsuming. ${ }^{117}$

Loser pays: In most legal systems, a losing civil plaintiff must pay the legal costs of the victorious defendant. "In most of Europe and Latin America, and much of the rest of the world, including ... . Canada, the rule is that the loser pays the winner's attorney fees ...."118 The resulting disincentive to civil litigation is obvious; one commentator lists this as the key obstacle to human rights litigation in English courts:

First and most importantly, the loser of a civil suit in England generally has to pay the legal costs incurred by the winner. This means that the average plaintiff in a human rights suit ... faces the very real possibility of hundreds of thousands of Pounds in legal bills. ${ }^{119}$

The hurdle is highest in cases raising novel legal theories, where the danger of losing is also greatest. In the United States, plaintiffs regularly bring cases of first impression, hoping to convince a court to establish new law or to apply existing theories to a new set of facts. In "loser pays" legal systems, such innovative efforts raise the risk of bankrupting the plaintiff. In such systems, plaintiffs "are discouraged from bringing 'novel or risky' cases, that is, those with a low probability of success." 120 Since human rights cases are generally both "novel and risky," the loser pays fee structure presents a daunting barrier to such litigation.

No contingency fees: The United States is unusual in its system of contingency fees, permitting attorneys to collect their fees as a percentage of a successful judgment. Contingency fee arrangements are prohibited in most

115. Id.

116. K.C. Fan, Commercial Litigation, Arbitration, and the Enforcement of Foreign Judgments and Arbitral Awards in the Republic of China, 13 LOY. L.A. INT'L \& COMP. L.J. 61, 63 (1990).

117. Código Procesal Civil y Comercial de la Nación art. 79 (Arg.), discussed in Romina Picolotti \& Juan M. Picolotti, Legal Responsibility of Corporations for Human Rights Abuses in Argentina, available at http://www.cedha.org.ar/doc23.htm (last visited Mar. 5, 2001).

118. MERRYMAN, supra note 93, at 1026; see also Werner Pfennigstorf, The European Experience with Attorney Fee Shifting, 47 LAW \& CONTEMP. PROBS. 37, 44 (1984) (stating that most European systems require the losing party to pay the winning party's attorney fees).

119. Michael Byers, English Courts and Serious Human Rights Violations Abroad: A Preliminary Assessment, in LIABIITY OF MULTNATIONAL CORPORATIONS UNDER INTERNATIONAL LAW 241, 244 (Menno T. Kamminga \& Saman Zia-Zarifi eds., 2000).

120. J. Robert S. Prichard, A Systemic Approach to Comparative Law: The Effect of Cost, Fee, and Financing Rules on the Development of the Substantive Law, 17 J. LEGAL STUD. 451, 460-61 (1988). In practice, a "loser pays" system may have built-in protections that lessen the risk. In Germany, for example, the fee owed by a losing plaintiff is generally determined by the amount in controversy; a plaintiff who could not afford to pay such an amount, however, can ask the court to artificially lower the value of the controversy and thereby reduce the potential penalty for losing. Hein Kotz, Civil Litigation and the Public Interest, I CIV. JUST. Q. 237, 248 (1987). 
countries, including almost all civil law systems. ${ }^{121}$ In the absence of such fees, private attorneys are less likely to invest their time and money in a risky lawsuit, because the possible reward is much less tempting-although huge contingency fees in human rights cases also trigger concerns about the fair allocation of any funds collected in such cases. ${ }^{122}$

High legal fees: The line of Filártiga litigation in the United States was developed by public interest lawyers, sometimes working with the assistance of law school clinics or private law firms working without fee. By contrast, efforts to undertake such litigation in other countries run into immediate concerns about legal fees. The cost of obtaining legal representation was one of the factors leading the Second Circuit to reject dismissal of the Wiwa case. ${ }^{123}$ Indeed, plaintiffs' expert concluded that it was "highly unlikely" that a law firm in England would obtain funding for the litigation, agree to pursue it on a conditional fee basis, or undertake it pro bono. ${ }^{124}$ When public funding is not available in England, efforts to pursue human rights cases are hampered by "the relative absence of a culture of volunteer work among English lawyers and law firms." ${ }^{25}$ The problem can be even more severe in other countries: The House of Lords has recognized inability to find legal representation as a reason why litigation in England should not be dismissed in favor of litigation in South Africa or Namibia for events arising in those countries. ${ }^{126}$

No punitive damages: Few nations award punitive damages, and none on the scale of the United States. ${ }^{127}$ The unlikelihood of a large judgment renders such litigation of less interest to the plaintiff, as well as to the attorneys, whose fee may be correspondingly smaller and/or more difficult to collect from the client. As discussed above, the absence of punitive damages also

121. MERRYMAN, supra note 93, at 1026. "Contingent fee contracts (pacta de quofa litis) in the litigation context have been disfavored in both the civil law tradition and the common law tradition, and today are illegal or unethical in most-but not all-countries outside the United States." Id. The civil law exceptions are Japan, Indonesia, and Thailand. Id.

122. In the litigation against the Estate of Ferdinand Marcos, for example, a private law firm representing a class of thousands of victims of abuses, sought a contingency fee of over $\$ 40$ million; the huge proposed fee aroused fierce protests from some members of the class. See, e.g., Teddy Casino, Fast Forward: Poorer But Richer, BuS. WORLD, Aug. 6, 1999, 4 (quoting some class members as describing a proposal to award the class $\$ 150$ million, with over $\$ 34$ million in contingency fees to the legal team, as "nauseating"); see also Matsumoto, supra note 95, at 579 (noting that in the absence of large contingency fees, attorneys rarely earn large fees on civil lawsuits).

123. "The plaintiffs have already obtained excellent pro bono counsel to litigate this matter in the courts of the United States; there is no guarantee that they will be able to obtain equivalent representation in England without incurring substantial expenses." Wiwa v. Royal Dutch Petroleum Co., 226 F.3d 88, 108 n. 13 (2d Cir. 2000).

124. Declaration of Richard Meeran, supra note 113, at 4, 8-9.

125. Byers, supra note 119 , at 244 .

126. Lubbe v. Cape PIc (No.2), 1 W.L.R. 1545 (H.L. 2000) (refusing to dismiss a case in favor of litigation in the home country where plaintiffs would be unable to fund legal representation in that country).

127. See Harvey McGregor, Personal Injury and Death, in 11 INTERNATIONAL ENCYCLOPEDIA OF COMPARATIVE LAW, ch. 9, at 4-6 (Andre Tunc ed., 1969). Many legal systems provide for moral damages, which take into account non-compensatory factors such as the egregiousness of the defendant's behavior and the defendant's ability to pay; the amounts awarded, however, do not approach the levels of U.S. punitive damages. Id. at 6-9; see also Matsumoto, supra note 95, at 579 (noting that damage awards in Japan do not tend to be excessive). 
renders a civil judgment purely compensatory, lacking the penal aspect of U.S. judgments, explaining in part the assumption that civil remedies are an inappropriate vehicle by which to seek redress for human rights violations.

Calculating damages: Where damages are calculated based on lost earnings or loss of support, the amounts recoverable on behalf of a working person in a poor community may be quite low, perhaps even too low to justify the costs of litigation. In some legal systems, the potential recovery will be raised by awards for non-pecuniary harm such as pain and suffering or loss of enjoyment of life, but others reject such categories of damages in all cases or, more commonly, reject them if the victim has died. ${ }^{128}$ Comparative studies of damage awards find not only that U.S. awards are much higher than those in any other country, ${ }^{129}$ but also find great disparities even within Europe and "a pattern of low awards" in jurisdictions where "the standard of living is low and the economy underdeveloped. ${ }^{.130}$ Moreover, amounts are much lower even in the more prosperous countries outside of Europe, such as Japan. ${ }^{131}$

Limited discovery: In the absence of discovery as a tool of investigation, plaintiffs must be prepared to prove their cases with the information available to them. This poses a barrier to civil litigation in general, one which applies as well to human rights cases. ${ }^{132}$

Application of international or foreign law: Many domestic legal systems do not recognize violations of international law as torts that give rise to a cause of action. ${ }^{133}$ Claims might be possible for domestic torts, such as wrongful death, assault, or false imprisonment, but not for summary execution, torture, or arbitrary detention. Such systems pose several problems. First, as one U.S. judge has noted, a claim based on an international human rights violation carries with it heightened condemnation and concern. An international human rights violation, Judge Woodlock wrote, should not be reduced "to no more (or less) than a garden-variety municipal tort."134

\footnotetext{
This is not merely a question of formalism or even of the amount or type of damages available: rather it concerns the proper characterization of the kind of wrongs meant to be addressed under [the U.S. statute]: those perpetrated by hostis humani generis ("enemies of all humankind") in contravention of jus cogens (peremptory norms of international law). In this light, municipal tort law is an inadequate placeholder for such values. ${ }^{135}$
}

In a footnote, the judge continues:

For example, I question the appropriateness of using a municipal wrongful death statute

128. See McGregor, supra note 127 , at 15-19 (discussing varying approaches to compensation for non-pecuniary losses).

129. Id. at 65 .

130. Id at 68 .

131. Id at 69 .

132. See Matsumoto, supra note 95 , at 578-79 (suggesting that difficulty in gathering evidence, caused by the lack of U.S.-style discovery procedures "is the principle reason why we have so small a number of product liability decisions" in Japan).

133. See, e.g., BRTISH ILA REPORT, supra note 5, at 158-59 (explaining the difficulty under British law of establishing a claim arising under customary international law).

134. Xuncax v. Gramajo, 886 F.Supp. 162, 183 (D. Mass. 1995).

135. Id. 
to address summary execution or "disappearances." Similarly, I doubt any municipal law is available to address the crime of genocide adequately. ${ }^{136}$

In the United States, the Alien Tort Claims Act and the related statutes authorize causes of action for violations of international human rights. No other legal system has a comparable statute. In some countries, such claims can be brought directly, pursuant to customary international law; such actions may, however, require complex and costly procedural prerequisites. In England, for example, proof of a right to sue under customary international law requires development of an extensive record that is likely to be time consuming, expensive, and difficult to achieve. ${ }^{137}$ Absent such a finding, civil claims must be litigated as what Judge Woodlock termed "garden-variety municipal torts."

This limitation was acknowledged by experts on both sides of the Wiwa litigation. ${ }^{138}$ Defendants argued that it made no difference to the forum non conveniens question, while plaintiffs insisted that a change of venue to a forum that would not classify the tort as a violation of international law would deprive the plaintiffs of the full scope of their claim.

Moreover, in the absence of a cause of action grounded in either domestic or international law, most courts would apply choice of law rules that would point to application of the law of the location where the abuses took place. ${ }^{139}$ If that nation has granted amnesty, or otherwise limited liability for human rights abuses, the forum country may conclude that the claim cannot be asserted. Plaintiffs in Wiwa pointed to an additional problem with applying domestic tort law to these international human rights claims: the local municipal law might not recognize the underlying facts as a tort at all. The Nigerian government executed Ken Saro-Wiwa and John Kpuinen after a show trial; if that trial and the execution were legal under Nigerian law, application of municipal law might compel a finding that no tort had been committed at all. Similarly, a municipal law system might not recognize certain acts of torture or arbitrary detention committed by government officials as torts.

This obstacle is heightened in England by a restriction on extraterritorial tort claims in English courts: such claims will not be sustained unless they would be recognized as actionable in the place where the underlying events took place. ${ }^{140}$ Thus, in Wiwa, if Nigerian law categorized the defendants' behavior as nontortious, they would be relieved of all tort liability in England as well. Such a requirement returns control over a plaintiff's claims to the legal system in which the abuses took place-a legal system that may be

136. Id. at 183 n.24.

137. BRTISH ILA REPORT, supra note 5, at 159.

138. See Duffy I, supra note 113, ff 9-13; Duffy II, supra note 113, If 2-4; Collins I, supra note 113, ๆी 17, 20; Collins II, supra note 113, ๆf 6-9; Collins III, supra note 113, $\mid 2$.

139. BRTISH ILA REPORT, supra note 5, at 140, 144, 160-62.

140. Until 1995, double actionability required that the acts be considered tortious under both the law of the place of the underlying events and the law of England. As of 1995, the requirement of a violation of English law has been eliminated. Id. at 159, $160 \mathrm{n} .41$. 
under the sway of the government responsible for the abuses and unlikely to afford redress for plaintiff's damages.

In some nations, it may be possible to avoid such a result through a finding that an amnesty or other waiver of liability, or a failure to characterize a police abuse as a human rights violation, violates public policy and thus should not be followed by the forum, but such results are not guaranteed. ${ }^{141}$ English courts, for example, will reject the application of local law if the result would violate English public policy. However, such exceptions are applied sparingly and create an enormous barrier to the initiation of litigation. ${ }^{142}$ This barrier is magnified by the impact of the loser pays rule: as discussed above, losing parties in England generally must pay the legal fees of the winner, making litigation based on unprecedented theories financially risky. ${ }^{143}$ In the United States, by contrast, the existence of the Alien Tort Claims Act and the Torture Victim Protection Act has been read by the courts as indicating a legislative policy favoring resolution of human rights claims in federal courts. In other words, the courts do not need to speculate about public policy but rather can follow the guidance of the legislature, resolving doubts in favor of permitting federal civil claims for egregious human rights abuses. ${ }^{144}$

Finally, in the absence of a domestic statute authorizing such claims, some domestic systems would be reluctant to find a cause of action based upon international norms. This problem of litigating international tort claims based on international human rights violations is the focus of a recent collection of essays, Torture as Tort, edited by Craig Scott. ${ }^{145}$ Scott asks in his introduction, "What does it take for (internationally-prohibited) torture to be transformed into (domestically-sanctioned) tort?"146 Several of the essays discuss the theoretical hurdle posed by the recognition of a private right of action based on public international human rights norms in the absence of national legislation authorizing such claims. Scott and most of the contributors to his volume conclude that existing doctrines permit the courts to overcome this barrier; they recognize, however, that the courts may find this step difficult. ${ }^{147}$

141. Id. at 163 ; Byers, supra note 119 , at 244 .

142. Application of the public policy exception was much debated in the Wiwa litigation. See Wiwa v. Royal Dutch Petroleum Co., 226 F.3d 88, 100-01 (2d Cir. 2000) (mentioning, without deciding, concerns about the possibility of overcoming various English legal hurdles). Plaintiffs agreed with defendants that the English courts are empowered to recognize public policy exceptions to the act of state doctrine and the double actionability rule. Plaintiffs' expert, however, concluded that application of this exception was unlikely. See Duffy I, supra note 113, fin 14-17; Duffy II, supra note 113, fiा 5-6.

143. See supra text accompanying notes 118-120; Meeran Declaration, supra note 113 (detailing high expenses and financial risks such litigation would entail in England).

144. See discussion of congressional public policy in favor of resolution of international human rights claims in U.S. courts in Wiwa, 226 F.3d at 103-06.

145. TORTURE AS TORT, supra note 5.

146. Craig Scott, Introduction to Torture as Tort: From Sudan to Canada to Somalia, in TORTURE AS TORT, supra note 5, at 3,7.

147. See, e.g., Anne C. McConville, Taking Jurisdiction in Transnational Human Rights Tort Litigation: Universality Jurisdiction's Relationship to Ex Juris Service, Forum Non Conveniens and the Presumption of Territoriality, in TORTURE AS TORT, supra note 5, at 157, 157-58 (concluding that 
The variations on these procedures are, of course, innumerable, but almost any one of them would be enough to render independent civil human rights litigation against non-national defendants an unattractive option. A combination of structural links between criminal and civil claims, sharply different cultural attitudes toward civil litigation, and procedures that make independent civil claims difficult if not impossible, explains the fact that the United States remains the home to core Filártiga litigation.

This review of the differences among varied national legal systems carries another important lesson. We should not expect to find identical means of enforcing international law in the domestic courts of different jurisdictions. Each system translates its international law obligations into proceedings that are appropriate to its domestic civil and criminal system. Indeed, even the very labels "civil" and "criminal" may have different meanings in different legal systems. International principles that distinguish among domestic actions based upon these categories fail to capture the richness of diverse national systems and may lead to inconsistent results. In particular, such ill-founded classifications risk unfairly excluding civil claims from their proper role as an internationally recognized means to implement international human rights norms.

In the final Part of this Article, I will apply these comparative law insights to an analysis of the principle of universal jurisdiction, which permits, or at times requires, national legal systems to adjudicate claims of international human rights abuses. Universal jurisdiction is often discussed outside of the United States as if it authorized only criminal prosecutions, but such a limitation cannot survive a comparative analysis of the highly diverse national legal systems. Both the history and the underlying logic of universal jurisdiction demonstrate that the principle encompasses a wide variety of domestic legal procedures. I thus conclude that civil Filártiga claims, properly translated, fit neatly into the mandate of universal jurisdiction and into the overall framework of the international accountability movement.

\section{TRANSLATING FILARTIGA: A MULTINATIONAL APPROACH To DOMESTIC REMEDIES}

International human rights law has developed rapidly over the past fifty years, and today provides a detailed elaboration of human rights norms. International mechanisms to enforce those norms, however, are still rudimentary. Domestic legal systems remain a crucial part of the enforcement process, filling part of the gap left by the dearth of international enforcement measures. As demonstrated in Parts II and III of this Article, domestic legal systems generally do not produce identical legal proceedings, a result of widely varied legal procedures and cultures. International norms are implemented in the legal "language" appropriate to national systems, a

although Canadian legal principles permit civil human rights claims, Ontario courts "may be reluctant" to resolve such claims "through private law actions derived from, or bolstered by, public international law norms"). 
process I have called "translation." In particular, core Filártiga litigation reflects the U.S. translation of accountability norms into a form appropriate to the U.S. legal system.

This comparative law insight is of particular importance to the interpretation of the international accountability principle of universal jurisdiction. Universal jurisdiction permits-or in some cases requiresnational legal systems to assert jurisdiction over perpetrators of human rights abuses. The doctrine is commonly applied to authorize criminal prosecutions. United States courts and scholars also regularly apply universal jurisdiction to civil Filártiga claims, a process that has not been replicated outside of the United States. With translation problems overcome, we can understand that these varied domestic procedures all implement the common mandate to hold accountable those who violate internationally protected human rights and thus fall within the reach of universal jurisdiction.

In this Part, I begin by placing Filártiga and the assorted domestic actions in other countries in context as part of a burgeoning practice of transnational law litigation. Such litigation reflects a multinational response to the international law demand for accountability. Next, I explore in detail universal jurisdiction and its application to civil claims, analyzing both the relevant history and its underlying logic to demonstrate that universal jurisdiction authorizes domestic legal systems to translate accountability principles into a variety of legal actions, civil as well as criminal. Finally, I urge that care be taken in negotiating an international agreement governing jurisdiction and the enforcement of judgments, in order to draft a convention that recognizes and accommodates this principle.

The future of an integrated approach to transnational law litigation depends upon the development of international law principles that acknowledge that our domestic law categories are not uniform, offer national systems the flexibility to provide redress through the practices appropriate to their legal structure, and avoid discriminating among such practices based on improperly "translated" procedures.

\section{A. Transnational Law Litigation: Contextualizing Filártiga}

Filártiga lawsuits-broad Filártiga-type cases as well as those falling within the core Filártiga doctrine-are part of a global campaign to enforce international human rights norms, which, in turn, is part of a larger effort to enforce international law in general. In this Part, I place Filártiga in the context of this broad effort to develop and enforce international law.

Enforcement of international law involves a wide range of procedures and a disparate network of institutions: governmental and nongovernmental; domestic, regional, and international; monitoring and adjudicatory; and voluntary and externally imposed. Professor Harold Koh has dubbed the varied mechanisms by which international norms are developed and 
eventually obeyed (most of the time) ${ }^{148}$ as "transnational legal process." This process involves "public and private actors-nation-states, international organizations, multinational enterprises, non-governmental organizations, and private individuals-[who] interact in a variety of public and private, domestic and international fora to make, to interpret, to enforce, and ultimately, to internalize rules of transnational law."149 Through these complex interactions, international rules are developed, interpreted, and eventually internalized. They are followed not just because obeying the law is convenient but because their rules become accepted tenets of global life. ${ }^{150}$

One piece of this complex process that has been of increasing relevance over the past 20 years is transnational law litigation, in which governments or private actors assert both international and domestic legal claims. ${ }^{151}$ As with impact litigation in a domestic forum, the parties seek a judicial declaration of the applicable law as a part of a long-term project aimed at furthering the development and enforcement of such norms. ${ }^{152}$ The "essence" of transnational law litigation, according to Koh, is "the coupling of a substantive notion-individual and state responsibility-with a familiar process - adjudication - and a normative goal-the promotion of universal norms of international conduct." ${ }^{\text {"153 }}$ Individual litigants, of course, have more immediate needs and interests in addition to these global goals, including compensation and punishment of the perpetrator. ${ }^{154}$ But, as with domestic impact litigation, transnational litigation contributes to the effective enforcement of legal norms as well.

148. As Professor Louis Henkin has famously said, "[A]lmost all nations observe almost all principles of international law and almost all of their obligations almost all of the time." How NATIONS BEHAVE 47 (2d ed. 1979).

149. Harold Hongju Koh, Transnational Legal Process, 75 NEB. L. REV. 181, 183-84 (1996).

150. See id. at 203-05.

151. See generally Koh, supra note 37.

152. Professor Harold Hongju Koh describes this process thus:

To summarize, transnational public law litigation is characterized by: (1) a transnational party structure, in which states and nonstate entities equally participate; (2) a transnational claim structure, in which violations of domestic and international, private and public law are all alleged in a single action; (3) a prospective focus, fixed as much upon obtaining judicial declaration of transnational norms as upon resolving past disputes; (4) the litigants' strategic awareness of the transportability of those norms to other domestic and international fora for use in judicial interpretation or political bargaining; and (5) a subsequent process of institutional dialogue among various domestic and international, judicial and political fora to achieve ultimate settlement.

Id. at 2371 (footnote omitted). One example on the international stage is the challenge to the legality of nuclear weapons filed in the International Court of Justice, which well illustrates an effort to use an international law adjudication to develop international norms through an ongoing process of litigation, dialogue, and debate. THE CASE AgAINST the BOMB: MARSHALl ISLANDS, SAMOA AND SOLOMON ISLANDS BEFORE THE INTERNATIONAL COURT OF JUSTICE IN ADVISORY PROCEEDINGS ON THE LEGALITY OF THE THREAT OR USE OF NUCLEAR WEAPONS (Roger S. Clark \& Madeleine Sann eds., 1996); VED P. NANDA \& DAVID KRIEGER, NUCLEAR WEAPONS AND THE WORLD COURT (1998).

153. Koh, supra note 37 , at 2372.

154. "International tort plaintiffs pursue not only norm enunciation, but also compensation, deterrence, and denial of safe haven to the defendant. Institutional reform plaintiffs additionally seek revision of governmental policies; and state plaintiffs pursue national and geopolitical objectives." Id at 2371-72. 
Commentators have long stressed the role of national courts in enforcing international law: in the absence of an international judiciary, most such enforcement necessarily comes through domestic judicial systems fulfilling a dual role as both national and international agents. ${ }^{155}$ As such, a national court functions as a kind of "transnational court." 156 Professor Aceves has emphasized that varied domestic claims play a role in this endeavor, including enforcement of administrative regulations, as well as criminal and civil proceedings:

Through transnational law litigation, states develop civil, criminal, and immigration responses to violations of human rights regardless of where such acts occur and enforce international human rights law at the national level, where vibrant enforcement mechanisms are already in place. This approach recognizes the relationship between domestic and intemational law. It affirms the role of domestic institutions in enforcing international obligations and acknowledges the critical role of individuals in this process. $^{157}$

Aceves stresses the range of litigation options included within the concept: civil, criminal, and immigration are all part of the "[u]niversal system of transnational law litigation." 158

Over the past ten years, criminal prosecutions of international law violations have occupied the central place in this process. After playing a crucial role in the aftermath of World War II, there were few such prosecutions during the following decades. ${ }^{159}$ But over the past ten years, two international criminal tribunals established by the U.N. Security Council have been followed by domestic criminal prosecutions for international violations in several countries under the principle of universal jurisdiction. The targets have included defendants accused of human rights violations in the former Yugoslavia, Rwanda, Chile, Argentina, Chad, the Democratic Republic of the Congo, Suriname, and Israel. ${ }^{160}$

155. See Antonio Cassese, Remarks on Scelle's Theory of "Role Splitting" (dedoublement fonctionnel) in International Law, I EUR. J. INT'L L. 210, 212-13, 228-30 (1990) (stating that international law is implemented by national bodies who operate in a dual role, as national agents and as international agents).

156. In transnational cases, courts "sit as transnational courts participating in a transnational lawmaking process." Harold G. Maier, Extraterritorial Jurisdiction at a Crossroads: An Intersection Between Public and Private International Law, 76 AM. J. INT'L L. 280, 320 (1982).

157. William J. Aceves, Liberalism and International Legal Scholarship: The Pinochet Case and the Move Toward A Universal System of Transnational Law Litigation, 41 HARV. INT'L L.J. 129, 132 (2000). In this article, Professor Aceves focuses exclusively on national judicial actions. I include bilateral, regional, and global adjudicatory bodies as well as national ones, recognizing the role played by the Intemational Court of Justice, the European Human Rights Court, and the Inter-American Human Rights Court.

158. Id. at 150. "[T] The law of nations . . . is enforced by . . . the municipal law of the country; which ... may ... facilitate or improve the execution of decisions, by any means they shall think best, provided the great universal law remains unaltered." Jordan J. Paust, On Human Rights: The Use of Human Rights Precepts in U.S. History and the Right to an Effective Remedy in Domestic Courts, 10 MICH. J. INT'L L. 543, 628 (1989) (quoting Ross v. Rittenhouse, 2 U.S. (2 Dall.) 160, 162 (1792)).

159. Adolf Eichmann and John Demjanjuk were tried in Israel on the basis of universal jurisdiction as well as other jurisdictional principles. INTERNATIONAL LAW ASSOCIATION, FINAL REPORT ON THE EXERCISE OF JURISDICTION IN RESPECT OF GROSS HUMAN RIGHTS OFFENCES 22-23 (2000) [hereinafter ILA U.J. REPORT].

160. In the well-publicized effort to prosecute Chilean General Augusto Pinochet, he was 
These criminal prosecutions are part of transnational law litigation, sharing global purposes as well as the particular goal of indicting and punishing a criminal defendant. International prosecutions aim to define and to publicize international rules of behavior and to deter future abuses, as well as to punish the defendants. Domestic criminal prosecutions for international crimes also serve to define and to publicize the law and to deter future violations.

The Pinochet extradition battle is a good example of the role that a criminal prosecution can play as part of transnational law litigation. The legal case began as a criminal investigation in Spain, initiated by private organizations. ${ }^{161}$ Although the Spanish prosecution was blocked when England released Pinochet on medical grounds, rather than permitting his extradition to Spain, the widespread publicity over the case prompted a seismic shift in public perceptions of accountability for human rights abuses committed as part of a state policy, catalyzing domestic prosecutions. In the words of Professor Roht-Arriaza, "The unthinkable became thinkable," with prosecutors and judges re-opening cases and investigations that had been stalled for decades. ${ }^{162}$ Even if these cases do not proceed to judgments, victims have received some measure of justice from the public airing of their stories, and Pinochet has been punished to some degree through public condemnation of his acts. Moreover, the Pinochet precedent has made a

detained while traveling in England based upon an extradition request arising out of a criminal investigation in Spain. After his arrest, France, Switzerland, and Belgium also requested Pinochet's extradition. He was released and allowed to leave England after a medical examination found him to be suffering from health problems. For a full discussion of the case, see Byers, supra note 1.

As of 1999, there had been eleven similar prosecutions in Europe, including six completed cases, in Switzerland, Denmark, Austria, and Germany, with four convictions and two acquittals. Five cases were still pending, in Belgium, France, Germany, and the Netherlands. REDREss, supra note 72, at 1. Cases have been filed in several European countries against former Argentine military officers for violations committed in that country. Id. at 11 .

More recently, a Senegalese judge indicted the former dictator of Chad on charges of torture, basing jurisdiction on the Torture Convention, supra note 16, although the charges were later dismissed. Reed Brody, The Prosecution of Hissene Habre-An "African Pinochet," 35 NEw ENG. L. REV. 321 (2001) (providing a full history of case); Human Rights Watch, Senegal Base Charges Against Ex-Chad Dictator: Habre's Victims Vow to Fight On, available at http://www.hrw.org/hrw/press/ 2001/03/habre0320.htm (reporting that Senegal's highest court upheld dismissal of charges against Habre on March 20,2001). In November 2000, a court in the Netherlands ordered the initiation of a criminal case against the former military dictator of Suriname. Marlise Simons, Dutch Court Orders an Investigation of ' 82 Killings in Suriname, N.Y. TMES, Nov. 26, 2000, at 12; International Commission for Jurists, available at http://www.icj.org/objectives/decision.htm. In a case that may lead to an international law evaluation of the scope of universal jurisdiction, Belgium has indicted an official of the Democratic Republic of the Congo for "serious violations of international humanitarian law," an action that has been challenged in the International Court of Justice. International Court of Justice Press Release 2001/17, Arrest Warrant of 11 April 2000, available at http://www.icj-cij.org/ icjwww/ipresscom/iprpencobe.html. Finally, an official criminal complaint has been filed in Belgium against the current prime minister of Israel, Ariel Sharon, charging him with responsibility for war crimes committed in massacres in the Sabra and Shatila refugee camps in Beirut in 1983. Massacre Survivors Seek Trial of Sharon in Belgium, THE GUARDIAN, June 19, 2001, available at http://www.guardian.co.uk/intemational/story/0,3604,509120,00.html.

161. See Roht-Arriaza, supra note 65 , at 311.

162. Id. at 315 . 
tremendous contribution to the development of international accountability norms.

The Filártiga cases are an example of the civil side of transnational law litigation. The goals of civil litigation closely parallel those sought in criminal prosecutions: punishment for past abuses; deterrence of future abuses; redress for victims, including compensation; and development of international law principles. Suits founded on domestic tort law can serve similar goals, even without labeling the bases for claims as international human rights abuses. Such actions have been filed in England, Canada, and Australia, asserting negligence claims arising out of corporate activities in foreign countries, where the firm is incorporated in the forum or has taken key decisions in its headquarters. ${ }^{163}$

Transnational law litigation also encompasses a range of administrative actions. ${ }^{164}$ The United States and many other nations, for example, have long used immigration restrictions to exclude those who participated in the Nazi persecution. ${ }^{165}$ Recent legislative initiatives propose extending these restrictions to all those who have committed egregious human rights abuses. ${ }^{166}$ Administrative actions to freeze or seize the bank accounts of those accused of human rights violations are also properly understood as a form of transnational law litigation. ${ }^{167}$

Each of these actions are part of the broad range of transnational law litigation. The various procedures involve public or private actors seeking redress in an international or domestic forum through a wide range of remedies that includes compensation to those injured as well as punishment of the perpetrators. In the next section, I explore the international law principles that permit or even require states to assert jurisdiction over such claims.

\section{B. Universal Jurisdiction over Transnational Law Litigation}

Transnational law litigation in domestic courts, a key component of the international accountability movement, encompasses a broad range of legal

163. Richard Meeran, Accountability of Transnationals for Human Rights Abuses-1, 148 NEW L.J. 1686 (1998); Richard Meeran, Accountability of Transnationals for Human Rights Abuses-2, 148 NEW L.J. 1706 (1998). The House of Lords recently rejected an effort to dismiss a series of cases in favor of a forum in South Africa. Lubbe v. Cape Plc, 1 W.L.R. 1545 (H.L. 2000).

164. Aceves, supra note 157, at 147-48 (discussing immigration restrictions as a "third form of transnational law litigation," along with criminal and civil actions).

165. William J. Aceves \& Paul L. Hoffman, Using Immigration Law to Protect Human Rights: A Legislative Proposal, 20 MICH. J. INT'L L. 657, 662-82 (1999) (describing Nazi exclusion provisions). into Congress).

166. Id. at 693 (detailing the authors' proposal); id. $694-96$ (describing a proposal introduced

167. See, e.g., Hilao v. Estate of Ferdinand Marcos (In re Estate of Ferdinand Marcos, Human Rights Litigation), 25 F.3d 1467, 1476-80 (9th Cir. 1994), cert. denied, 513 U.S. 1126 (1995) (affirming injunction preventing the Marcos estate from disposing of assets, including Swiss bank accounts); Sokol Braha, The Changing Nature of U.S. Sanctions Against Yugoslovia, 8 MSU-DCL J. INT'L L. 273 (1999) (describing U.S. economic sanctions in general and as applied to Yugoslavia, including freezing of assets); Naomi Roht-Arriaza, Truth Commissions and Amnesties in Latin America: The Second Generation, 92 CONTEMP. INT'L L. IsSUES 313, 315 (1998) (describing a proceeding in which a Spanish court asked Switzerland to freeze assets of some forty Argentine military officers under investigation for human rights abuses in Argentina). 
actions. Where the litigation involves events or actors based in the forum state, jurisdiction is based upon traditional notions of state authority to regulate events within its borders. To the extent that domestic transnational law litigation addresses abuses arising out of events in a foreign country and targets defendants who are not citizens or residents of the forum state, it must rely on an extraterritorial justification for the forum state's assertion of jurisdiction.

International law has long recognized universal jurisdiction over a small set of offenses of concern to all states. Much of the analysis of universal jurisdiction outside of the United States focuses on criminal prosecutions, omitting civil proceedings. A recent report on universal jurisdiction by the International Law Association, for example, focused exclusively on criminal actions, while mentioning in a footnote that "in the United States universal jurisdiction has been exercised with some success for the purpose of obtaining civil law remedies under the Alien Tort Claims Act and the Torture Victim Protection Act." 168

This tendency to separate the analysis of civil and criminal responses to international human rights violations is, in part, responsible for the lack of understanding of the Filartiga line of cases outside of the United States. As we shall see, however, the exclusive focus on criminal universal jurisdiction is the product of a translation failure, a failure that results in a skewed analysis of the diverse legal systems of the world. Relying on the comparative analysis of the prior sections, I argue here that such a distinction is misplaced, given that domestic legal systems translate their international obligations into a wide range of local proceedings appropriate to their systems. Properly translated, these varied actions all fall within the broad authorization of universal jurisdiction.

\section{Universal Jurisdiction to Redress Human Rights Violations}

Although territoriality remains central to modern notions of jurisdiction, ${ }^{169}$ exceptions are at least as old as the rule itself. ${ }^{170}$ Universal note 3).

168. ILA U.J. REPORT, supra note 159, at 3 n.6 (citing Stephens, Expanding Remedies, supra

169. "The starting-point in this part of the law is the proposition that, at least as a presumption, jurisdiction is territorial." IAN BROWNLIE, PRINCIPLES OF PUBLIC INTERNATTONAL LAW 298 (4th ed. 1990).

170. Early legal systems, for example, recognized that citizens traveling in other countries remained bound by the laws of their home country, not those of the countries in which they traveled. Max Rheinstein, The Constitutional Bases of Jurisdiction, 22 U. CHI. L. REV. 775, 802-03 (1955) (explaining that Rome, for example, developed two systems of law: civil law governed citizens of Rome, while the "law of nations" governed noncitizens). As far back as the 13th century B.C., governments negotiated agreements whereby their own laws would govern their citizens while in a foreign land. Michael Goldsmith \& Vicki Rinne, Civil RICO, Foreign Defendants, and "ET", 73 MNN. L. REV. 1023, 1026 n.14 (1989). Justice Frankfurter examined the history of this system in a long concurring opinion in Reid v. Covert, 354 U.S. 1, 41, 58 (1957) ("Historians have traced grants of extraterritorial rights as far back as the permission given by Egypt in the 12th or 13th century B.C. to the merchants of Tyre to establish factories on the Nile and to live under their own law and practice their own religion."). 
jurisdiction, one such exception, dispenses completely with a requirement of a particular connection between a state and the activities under review, relying instead on the collective interest that establishes a tie not to any one country, but to all states. ${ }^{171}$ Universal jurisdiction "recognize[s] that international law permits any state to apply its laws to punish certain offenses although the state has no links of territory with the offense, or of nationality with the offender (or even the victim)." ${ }^{\text {"172 }}$ The concept is of ancient pedigree, having been recognized for centuries. "[I]n many continental countries the universality principle is as ancient as the territoriality principle. ... It existed in medieval Italy, sixteenth-century Brittany, seventeenth- and eighteenth-century France until 1782, and seventeenth- and eighteenth-century Germany."173 Today, universal jurisdiction is still recognized as applying to pirates and slave traders, the "prototypal offenses that any state can define and punish,", also to genocide, war crimes, crimes against humanity, and torture. ${ }^{175}$

The common goal underlying universal jurisdiction is the international interest in deterring and punishing acts viewed as an "attack upon the international order as a whole." ${ }^{.176}$ The focus is on both the heinousness of the

171. See, e.g., BROWNLE, supra note $169,300-05$.

172. The RESTATEMENT (THIRD) OF THE FOREIGN RELATIONS LAW OF THE UNIED STATES $§$ $402 \mathrm{cmt}$ a (1987) [hereinafter RESTATEMENT (THIRD)]. A U.S. federal court recognized the application of universal jurisdiction in In Matter of Demjanjuk.

International law provides that certain offenses may be punished by any state because the offenders are "common enemies of all mankind and all nations have an equal interest in their apprehension and punishment." ... The power to try and punish an offense against the common law of nations, such as the law and customs of war, stems from the sovereign character of each independent state, not from the state's relationship to the perpetrator, victim or act.

612 F.Supp. 544, 556 (N.D. Ohio 1985), aff'd, 776 F.2d 571 (6th Cir. 1985), cert. denied, 475 U.S. 1016 (1986).

173. Akehurst, supra note 89, at 163 (citations omitted). In the words of Vattel:

[A]lthough the justice of each nation ought in general to be confined to the punishment of crimes committed in its own territories, we ought to except from this rule those villains, who, by the nature and habitual frequency of their crimes, violate all public security, and declare themselves the enemies of the human race. Poisoners, assassins, and incendiaries by profession, may be exterminated wherever they are seized; for they attack and injure all nations, by trampling under foot the foundation of their common safety. Thus pirates are sent to the gibbet by the first into whose hands they fall.

E. DE VATTEL, THE LAW OF NATTONS 232, 233 (J. Chitty ed., new ed., Philadelphia, $T$ \& J.W. Johnson \& Co. 1876) (1758), quoted in Jeffrey M. Blum \& Ralph G. Steinhardt, Federal Jurisdiction over International Human Rights Claims: The Alien Tort Claims Act After Filartiga v. Peña-Irala, 22 HARV. INr'L L.J. 53, 60 n.36 (1981). Blum and Steinhardt note that the common denominator of these crimes is both the magnitude of the threat posed by the acts and universality of the international condemnation. Id. at 61.

174. Kenneth C. Randall, Universal Jurisdiction Under International Law, 66 TEX. L. REv. 785,788 (1988).

175. IIA U.J. REPORT, supra note 159, at 4-9. The ILA U.J. Report focuses on these violations, while noting that there is international support for others, including forced disappearances. Id. at 8 . Randall also lists terrorism, hijacking and sabotage of aircraft, apartheid, and other human rights violations. Randall, supra note 174, at 789. The Restatement defines universal jurisdiction as applying to "certain offenses recognized by the community of nations as of universal concern," and offers as examples a non-exclusive list including piracy, slave trade, attacks on or hijacking of aircraft, genocide and war crimes. RESTATEMENT (THIRD), supra note 172, § 404.

176. Mann, supra note 89 , at 9 . The territoriality principle does not apply to offenses "generally regarded as offenses of an international character of serious concern to the international community as a 
offense and the difficulty of bringing perpetrators to justice. ${ }^{177}$ As universal jurisdiction has expanded to include international human rights abuses, the rationale has remained the same, focusing on "offenses against the conscience of the civilized world," and "signal[ing] that they are so appalling that they represent a threat to the international legal order." ${ }^{\text {178 }}$ Perpetrators of gross human rights abuses, like pirates, are difficult to apprehend and bring to justice. ${ }^{179}$

Universal jurisdiction today is a product of both treaty and customary law. Two modern conventions obligate states to exercise universal jurisdiction. The Geneva Conventions impose universal jurisdiction for "grave breaches," including willful killing, torture, inhumane treatment and willfully causing great suffering. ${ }^{180}$ A party to the Conventions is required "to search for persons alleged to have committed, or to have been ordered to be committed, such grave breaches, and shall bring such persons, regardless of their nationality, before its own courts." 181 A. Party to the Convention Against Torture is required to either extradite or prosecute an alleged offender present in its territory. ${ }^{182}$ Both of these conventions require that state parties exercise

whole, which it is accepted may be punished by whichever state has custody of the offender." 1 OPPENHEIM'S INTERNATIONAL LAW 469 (Robert Jennings \& Arthur Watts eds., 9th ed. 1992).

177. As Edwin Dickinson has written:

So heinous is the offense considered, so difficult are such offenders to apprehend, and so universal is the interest in their prompt arrest and punishment, that they have long been regarded as outlaws and the enemies of all mankind. They are international criminals. It follows that they may be arrested by the authorized agents of any state and taken in for trial anywhere. The jurisdiction is universal.

Edwin Dickinson, Is the Crime of Piracy Obsolete?, 38 HARV. L. REV. 334, 338 (1925).

178. ILA U.J. REPORT, supra note 159 , at 3 .

179. "[W]ar crimes and crimes against humanity are analogous to piracy in that they are typically committed in locations where they will not be prevented or punished easily; this parailel suggests the necessity of extending universal jurisdiction" to such offenses. Randall, supra note 174, at 803-04; see also Willard B. Cowles, Universality of Jurisdiction Over War Crimes, 33 CAL. L. REV. 177,194 (1945) ("[T]here is often no well-organized police or judicial system at the place where the acts are committed, and both the pirate and the war criminal take advantage of this fact, hoping thereby to commit their crimes with impunity.").

180. Articles 50, 51, 130 and 147 of the First, Second, Third, and Fourth Geneva Conventions, respectively. Convention for the Amelioration of the Condition of the Wounded and Sick in Armed Forces in the Field, Aug. 12, 1949, 6 U.S.T. 3114, 75 U.N.T.S. 31 [hereinafter Geneva Convention I]; Convention for the Amelioration of the Condition of Wounded, Sick and Shipwrecked Members of Armed Forces at Sea, Aug. 12, 1949, 6 U.S.T. 321, 75 U.N.T.S. 85 [hereinafter Geneva Convention II]; Convention Relative to the Treatment of Prisoners of War, Aug. 12, 1949, 6 U.S.T. 3316, 75 U.N.T.S. 135 [hereinafter Geneva Convention III]; Convention Relative to the Protection of Civilian Persons in Time of War, Aug. 12, 1949, 6 U.S.T. 3516, 75 U.N.T.S. 287 [hereinafter Geneva Convention IV]. These particular grave breaches apply only to "international conflicts." In addition, universal jurisdiction may also apply to gross violations committed during internal conflicts. See ILA U.J. REPORT, supra note 159, at 6-7 (citing several international sources in support of the view that universal jurisdiction applies without distinction between international and internal armed conflicts).

181. See Geneva Convention I, supra note 180, art. 49; Geneva Convention II, supra note 180, art. 50; Geneva Convention III, supra note 180, art. 129; Geneva Convention IV, supra note 180, art. 146.

182. Torture Convention, supra note 16 , art. $5, \S 2$. The provisions of the Genocide Convention, supra note 18, are arguably weaker: state parties pledge to prosecute those responsible for genocide in their own territory, arts. 5-6, and to extradite them to other countries "in accordance with their laws and treaties in force," art. 7.

Several of the treaties addressing terrorism also provide for universal jurisdiction. See, e.g., 
universal jurisdiction, at least as a "fallback" in circumstances in which prosecution is not possible in the country where the abuses took place. ${ }^{183}$ In addition, customary international law, at a minimum, permits all states to exercise universal jurisdiction over genocide, crimes against humanity, war crimes, and torture. ${ }^{184}$

As recounted in the previous section, domestic legal systems have relied upon universal jurisdiction to support criminal prosecutions for human rights violations. Most rested jurisdiction upon treaties that obligated the assertion of universal jurisdiction, such as the Geneva Conventions or the Convention Against Torture, although the Belgian courts asserted universal jurisdiction over a charge of crimes against humanity based on customary international law. In that case, Chileans living in Belgium filed a criminal complaint against Augusto Pinochet, alleging violations of international law. ${ }^{185}$ The investigating magistrate found that "as a matter of customary international law, or even more strongly as a matter of jus cogens, universal jurisdiction over crimes against humanity exists, authorizing national judicial authorities to prosecute and punish the perpetrators in all circumstances." 186 Other courts have relied upon customary international law to supplement treaties. In particular, although the Genocide Convention does not require the assertion of jurisdiction by national courts of another state, domestic courts have found universal jurisdiction over extraterritorial acts of genocide based on customary international law. ${ }^{187}$

Despite the broad reach of universal jurisdiction, states have traditionally been reluctant to take advantage of the doctrine's full potential. Many have imposed limits through narrow domestic implementation statutes, restricting the range of offenses, the time period, or the geographic location of the abuses subject to universal jurisdiction. ${ }^{188}$ The theoretical framework for

Convention for the Suppression of Unlawful Seizure of Aircraft, Dec. 16, 1970, 22 U.S.T. 1641, 860 U.N.T.S. 105; International Convention Against the Taking of Hostages, Dec. 17, 1979, TIAS No. 11,081, 1316 U.N.T.S. 205; International Convention for the Suppression of Terrorist Bombings, 37 I.L.M. 249 (1998). See also International Convention on the Suppression and Punishment of the Crime of Apartheid, entered into force July 18, 1976, U.N. Doc. A/2645 (1953). See additional treaties cited in Roger S. Clark, Offenses of International Concern: Multilateral State Treaty Practice in the Forty Years Since Nuremberg, 57 NORDIC J. INT'L L. 49 (1988) (providing a comprehensive analysis of treaty provisions authorizing universal jurisdiction).

183. Professor Clark analyzed the language and negotiating history of a dozen treaties providing for universal jurisdiction, concluding that they each, at a minimum, require the exercise of universal jurisdiction as a "last resort." That is, if a violator is physically present in a state's territory, the state is required to exercise jurisdiction over the accused unless extradition for prosecution in an alternative forum is arranged. Clark, supra note 182 , at 85 .

184. ILA U.J. REPORT, supra note 159, at 4-5.

185. The case is summarized and analyzed in Luc Reydams, International Decision: Belgian Tribunal of First Instance of Brussels, Nov. 8, 1998, 93 AM. J. INT'L L. 700 (1999).

186. Id. at 702 .

187. See ILA. U.J. REPORT, supra note 159 , at 5 . Although some of the criminal prosecutions were also based upon the passive personality principle, where the victims were citizens of the forum state, others were based completely on universal jurisdiction, with no specific link between the forum and the defendant or his crimes. Id at 9-10.

188. Id at 10-12. Such statutes generally require the physical presence of the accused in the forum state. Id. The Security Council's authorization of international criminal tribunals for the former Yugoslavia and for Rwanda, and the approval of the statute of the International Criminal Court may 
universal jurisdiction, however, is well established, with a long historical pedigree. As applied to the broad range of transnational law litigation, including Filártiga-type cases, the key step is to recognize that this wellestablished international law doctrine authorizes jurisdiction over civil claims as well as criminal prosecutions.

\section{Dismantling the Criminal/Civil Divide}

An effort to impose a sharp distinction between international law's treatment of criminal and civil actions misunderstands domestic law divisions between civil and criminal actions. Rather than constituting a fixed, objective line, the civil/criminal distinction is a fluctuating product of policy decisions that change over time and between legal systems.

Even within the United States, drawing the line between civil and criminal is a difficult task. The Supreme Court's reasoning on issues such as the meaning of punishment, punitive damages, and property forfeiture has been described as "an incoherent muddle," as the Court seeks to determine when the constitutional protections for criminal prosecutions apply. ${ }^{189}$ Although a national legal system might define the line between the civil and the criminal with more success than the United States, such a line would still not effectively reflect the myriad legal systems around the world. Across national borders, such line-drawing is even more difficult. As discussed earlier, national legal systems draw the line between civil and criminal in different ways. In some systems, criminal prosecutions are always public actions; in others, they can be initiated and prosecuted by private parties. Conversely, governments can initiate civil actions that can be as onerous and "punishing" to the civil defendants as criminal prosecutions. ${ }^{190}$

Similar disparities are evident in terms of the consequences attached to civil and criminal proceedings. In some systems, damages for civil claims are always compensatory, in others they serve as a form of punishment as well. Some crimes are punishable only by fines or orders to compensate the victim, while some civil offenses can lead to imprisonment. Moreover, while most crimes are associated with moral condemnation, some regulatory crimes may be viewed as minor transgressions. On the other hand, torts that affect public health and safety may trigger society's moral outrage. The varieties of civil and criminal claims in domestic legal systems seeking redress for human rights violations span these different categories, with their exact categorization dependent on the definitions used by each system. Lawyers trained in different

trigger states to revise their domestic statutes to broaden the authorization of national prosecutions based on universal jurisdiction. Id at $9,12,24$.

189. Wayne A. Logan, The Ex Post Facto Clause and the Jurisprudence of Punishment, 35 AM. CRIM. L. REV. 1261, 1268 (1998).

190. In recognition of this, the European Human Rights Court has held that the defendants in such civil claims must be afforded the same protections as defendants in criminal trials. Guy Stessens, Corporate Criminal Liability: A Comparative Perspective, 43 INT'L \& COMP. L.Q. 493, 504-05 (1994) (noting that the European Court of Human Rights has concluded that certain administrative proceedings are "criminal in nature" and trigger protections associated with criminal prosecutions, no matter the label assigned to the action by the national legal system). 
legal systems have difficulty recognizing such distinctions, as civil and criminal remedies intertwine and overlap in unfamiliar ways.

Historically, the lines between torts and crimes have also changed and blurred. Wrongs have been redressed through public or private initiatives that imposed sanctions and demanded compensation without regard for such categories. Offenses were punished by monetary fines or imprisonment, without distinction between public and private wrongs or between torts and crimes. ${ }^{191}$ Criminal prosecutions encompassed a range of public and private actions, litigated by public prosecutors and/or private parties-sometimes the victim of an offense, sometimes a stranger. ${ }^{192}$

Indeed, viewed through either a comparative or historical lens, the classification of torts and crimes varies widely over many dimensions. Professor Friedman presents a persuasive argument that the categories are largely a false construct. ${ }^{193} \mathrm{He}$ charts the manner in which modern and historical legal systems classify actions based on whether the government or the individual controls the prosecution, whether fines are viewed as punishment or compensation, whether enforcement is intended to deter violations or to impose a price, and whether conviction involves a moral stigma ${ }^{194}$ Friedman finds a wide variety in the definitions of torts and crimes, concluding that "outside of the accidents of a particular legal system at a particular time, there is no natural category of tort or crime and thus no essential distinction." 195

\footnotetext{
The right question to ask is not what the essential distinction is between tort and crime; there is none. The right question is how choices in the different dimensions relate to each other, and what makes particular combinations of choices more or less appropriate for dealing with particular kinds of offenses in a particular society. ${ }^{196}$
}

Over time and across borders, legal systems have made different judgments as to which set of sanctions to apply to which offenses. The categories do not translate directly into the legal languages of different legal systems because they reflect a series of policy choices that vary across national borders.

In the context of efforts to enforce human rights norms, the particular label that a given domestic legal system applies to an action is therefore of little relevance. Public international law simply cannot depend upon the line between civil and criminal as a basis for drawing a meaningful distinction. The more appropriate question, as Professor Friedman's analysis suggests, is whether a particular set of procedures and sanctions is suited to the goals of international accountability. Those goals include not only punishment of the perpetrator but also remedies that address the needs of those injured by human rights violations, including compensation. To the extent that civil actions in many systems provide one means of obtaining compensation for victims of

191. Stephens, Federalism and Foreign Affairs, supra note 3, at 509-510.

192. Id. at 510 .

193. David Friedman, Beyond the Tort/Crime Distinction, 76 B.U. L. REv. 103 (1996).

194. Id. at 109.

195. Id. at $108-09$

196. Id. at 110 . 
abuses, civil claims fit comfortably within the framework of international law and universal jurisdiction, a topic to which I turn next.

\section{The Right to Compensation for International Human Rights Violations}

A discussion of international jurisdictional rules must take into account the obligations owed to victims of human rights abuses. Punishment of perpetrators is only part of the task. Indeed, international law has long recognized two halves of the accountability equation: punishment and compensation. In the eighteenth century, for example, de Vattel called for both punishment and reparation for violations of the law of nations:

Whoever offends the state, injures its rights, disturbs its tranquility, or does it a prejudice in any manner whatsoever, declares himself its enemy, and exposes himself to be justly punished for it .... [The sovereign] should avenge his wrongs, punish the aggressor, and, if possible, oblige him to make full reparation .... 197

Thus, the law of prize not only detailed the rules governing the legality of captures of enemy and neutral ships, but also provided for compensation for damage to individuals or property during the capture. ${ }^{198}$ Seizures of ships at sea in violation of international law regularly triggered both punishment of the culprit and compensation to the victim. ${ }^{199}$ In an early U.S. case addressing a violation of international neutrality obligations, leading members of the fledgling U.S. government discussed the range of remedies available in response to violations of international law. ${ }^{200}$ As Judge Wilson instructed the grand jury hearing the case, the offending individual should be punished and also ordered to pay reparations:

Let such be held responsible, when they can be rendered amenable for the consequences of their crimes and disorders. If the offended nation have the criminal in its power, it may without difficulty punish him, and oblige him to make satisfaction. When the offending citizen escapes into his own country, his nation should oblige him to repair the damage, if reparation can be made, or should punish him according to the measure of his offense. ${ }^{201}$

Punishment and reparations to those injured were seen as complementary pieces of the enforcement puzzle.

Modern international law recognizes that states have an obligation to offer remedies to victims of human rights abuses. ${ }^{202}$ States are obligated to

197. VATTEL, supra note 173 , at 161.

198. See William S. Dodge, The Historical Origins of the Alien Tort Statute: A Response to the "Originalists," 19 HASTINGS INT'L \& COMP. L. REV. 221, 243-44, 246 (1996).

199. See, e.g., Talbot v. Janson, 3 U.S. (3 Dall.) 133, 161 (1775) (ordering restitution after seizure of a ship in violation of the law of nations); United States v. La Vengeance, 3 U.S. (3 Dall.) 297 (1796) (civil proceeding seeking forfeiture of ship as punishment for violation of neutrality).

200. See Henfield's Case, 11 F.Cas. 1099 (C.C.D. Pa. 1793) (No. 6360).

201. Id. at 1108 (Wilson, J.); see also Blum \& Steinhardt, supra note 173, at $61 \mathrm{n.41;}$ Paust, supra note 158, at 623-624 ("Civil and criminal sanctions for private violations of international law were often interchangeable depending on who was seeking enforcement, an individual, the government or both.").

202. For a more extensive treatment of the right to a remedy under international law, see Beth 
ensure civil, administrative, or disciplinary proceedings, where appropriate, as a means to ensure adequate sanctions. ${ }^{203}$ The Universal Declaration of Human Rights states explicitly: "Everyone has the right to an effective remedy by the competent national tribunals for acts violating . . fundamental rights. . ., 204 The International Covenant on Civil and Political Rights spells out the content of this "effective remedy," requiring states "to develop the possibilities of judicial remedy," and "to ensure that the competent authorities shall enforce such remedies when granted." ${ }^{205}$ Several international agreements contain similar obligations, ${ }^{206}$ while others also specifically protect the right to compensation. ${ }^{207}$ In 1988, the Sub-Commission of the U.N. Human Rights Commission declared:

[A]ll victims of gross violations of human rights and fundamental freedoms should be entitled to restitution, a fair and just compensation and the means for as full a rehabilitation as possible for any damage suffered by such victims, either individually or collectively. ${ }^{208}$

Stephens, The Civil Lawsuit as a Remedy for International Human Rights Violations Against Women, 5 HASTINGS WOMEN's L.J. 143, 165-69 (1994).

203. Thus, the U.N. Special Rapporteur on Impunity has defined impunity as "the impossibility, de jure or de facto, of bringing the perpetrators of human rights violations to accountwhether in criminal, civil, administrative or disciplinary proceedings . . ." Question of the Impunity of Perpetrators of Violations of Human Rights (civil and political rights): Revised final Report prepared by Mr. Joinet, Pursuant to Sub-Commission Resolution 1996/119, Sub-Commission on Prevention of Discrimination and Protection of Minorities, 49th Sess., Item 10, at 3 UN Doc. E/CN.4/Sub.2/1997/20 (June 26, 1997).

204. Universal Declaration of Human Rights, art. 8, G.A. Res. 217A (III), U.N. GAOR, 3d Sess., Supp. No. 49, U.N. Doc. A/810 (1948).

205. International Covenant on Civil and Political Rights, Dec. 19, 1966, art. 2(3), 999 U.N.T.S. 171, reprinted in 6 I.L.M. 368 (1967) [hereinafter ICCPR].

206. Article 8(1) of the American Convention on Human Rights provides: "Every person has the right to a hearing, with due guarantees and within a reasonable time, by a competent, independent, and impartial tribunal, previously established by law ... for the determination of his rights and obligations of a civil, labor, fiscal, or any other nature." American Convention on Human Rights, opened for signature Nov. 22, 1969, art. 8(1), O.A.S.T.S. No. 36 at 1, O.A.S. Doc. OEA/Ser. L/V/II.50, doc. 6 at 27 (1980), reprinted in 9 I.L.M. 673 (1970) (entered into force July 18, 1978); see also European Convention for the Protection of Human Rights and Fundamental Freedoms, Nov. 4, 1950, art. 13, 213 U.N.T.S. 222 (entered into force Sept. 3, 1953); Declaration of Basic Principles of Justice for Victims of Crime and Abuse of Power, G.A. Res. 40/34, adopted Nov. 29, 1985, arts. 4, 18-21. The Convention on the Elimination of All Forms of Racial Discrimination states: "Everyone shall have the right to an effective remedy and protection against any discrimination he may suffer on the ground of race, color or ethnic origin with respect to his fundamental rights and freedoms." Art. 7, 5 I.L.M. 352 (1966), entered into force Jan. 4, 1969.

207. See, e.g., Torture Convention, supra note 16, art. 14; ICCPR, supra note 205, art. $9(5)$; American Convention on Human Rights, supra note 206, art. 63(1); European Convention, supra note 206, art 5(5); Declaration of Basic Principles of Justice for Victims of Crime and Abuse of Power, supra note 206, arts. 8-21. See Naomi Roht-Arriaza, State Responsibility to Investigate and Prosecute Grave Human Rights Violations in International Law, 78 CAL. L. REV. 451, 482 (1990).

The Declaration on the Protection of All Persons from Enforced Disappearance states that individuals responsible for forced disappearances are liable under civil law. G.A. Res. 47/133, U.N. GAOR, 47th Sess., Supp. No. 49, at 207, U.N. Doc. A/47/49 (1992), adopted Dec. 18, 1992.

208. Review of Further Developments in Fields with which the Sub-Commission has Been Concerned: Study Concerning the Right to Restitution, Compensation and Rehabilitation for Victims of Gross Violations of Human Rights and Fundamental Freedoms: Preliminary Report Submitted by Mr. Theo van Boven, Special Rapporteur, Commission on Human Rights, Sub-Commission on the Prevention of Discrimination and Protection of Minorities, U.N. ESCOR, 42d Sess., at 1, U.N. Doc. 
A Special Rapporteur, Professor Theo Van Boven, ${ }^{209}$ placed the responsibility for protecting these rights squarely on governments, including the obligation to open their legal systems to claims by victims and survivors of human rights abuses:

\begin{abstract}
As a matter of principle every State has the responsibility to redress human rights violations and to enable the victims to exercise their right to reparation. . . . Every State owes it to the victims of gross violations of human rights to see to it that ... those who have suffered receive reparation. The legal system of every State should, therefore, deal with such issues in a just and effective manner. ${ }^{210}$
\end{abstract}

In general terms, then, an "effective remedy" includes the right to bring claims before a judicial system capable of resolving allegations of human rights abuses, issuing judgments, and granting enforceable awards of compensation. ${ }^{211}$ In addition, the Convention Against Torture requires states party to the agreement to provide an "enforceable right to fair and adequate compensation.",212

The right-to-compensation requirement can be met by very different legal proceedings: criminal prosecutions may include claims for compensation, and truth commissions as well as other administrative bodies may be empowered to award reparations. In a follow-up to Van Boven's work, the new Special Rapporteur explains that states shall "[a]dopt appropriate and effective judicial and administrative procedures and other appropriate measures that provide fair, effective, and prompt access to justice," make available "adequate, effective, and prompt reparation," and "[a]fford appropriate remedies to victims." piece of the broad spectrum of legal remedies that states are obligated to afford to victims and survivors of human rights abuses.

E/CN.4/Sub.2/1990/10 (1990) (quoting Sub-Commission on the Prevention of Discrimination and Protection of Minorities, Resolution 1988/11 (Sept. 1, 1988)).

209. The Special Rapporteur was appointed pursuant to Resolution 1989/13, endorsed by the U.N. Commission of Human Rights in Resolution 1990/35, March 2, 1990 and by the U.N. Economic and Social Council, Resolution 1990/36, May 25, 1990. In 1998, the Commission appointed a new Special Rapporteur, M. Cherif Bassiouni, to revise the drafted basic principles on reparation with the goal of submitting the draft to the General Assembly for adoption. U.N. Doc. E/CN.4/1998/43, ๆ 2 .

210. Study Concerning the Right to Restitution, Compensation and Rehabilitation for Victims of Gross Violations of Human Rights and Fundamental Freedoms, Second Progress Report submitted by Mr. Theo Van Boven, Special Rapporteur, U.N. ESCOR, 45th Sess., Annex, of 6, 21, U.N. Doc. E/CN.4/Sub.2/1992/B (1992). See also Final Report Submitted by Mr. Theo Van Boven, Special Rapporteur, U.N. ESCOR, 45th Sess., U.N. Doc. E/CN.4/Sub.2/1993/8 (1993). See also Right to Restitution, Compensation and Rehabilitation for Victims of Grave Violations of Human Rights and Fundamental Freedoms, Final Report of the Special Rapporteur, Mr. M. Cherif Bassiouni, E.CN.4/2000/62 [hereinafter Bassiouni Report].

211. Roht-Arriaza, supra note 207 , at 479 .

212. The Convention provides:

Each State Party shall ensure in its legal system that the victim of an act of torture obtains redress and has an enforceable right to fair and adequate compensation, including the means for as full rehabilitation as possible. In the event of the death of the victim as a result of an act of torture, his dependants shall be entitled to compensation.

Convention Against Torture, supra note 16, art. 14.

213. Bassiouni Report, supra note $210, \S \S 2$ (b), 2(c), 3(d). 
It is important to note that the language in these documents generally does not limit this obligation to instances where the abuses took place in the forum state or where the forum state otherwise bears responsibility for the harms caused. That is, they are not explicitly limited to a territory-based remedial scheme. A broad interpretation of these international norms, therefore, would conclude that all states are obligated to offer all victims of human rights abuses access to judicial remedies, to enable them to secure compensation from those responsible. However, without debating whether access to such extraterritorial remedies might be obligatory, it is sufficient for my purposes to stress that these principles support the conclusion that states at the very least are permitted to offer civil remedies for violations of international law, no matter where those abuses took place.

\section{Universal Jurisdiction Reexamined}

Universal jurisdiction permits domestic legal systems to assert extraterritorial jurisdiction over a growing list of international offenses and requires them to do so in some circumstances. This international law principle, however, must be translated into legal proceedings appropriate to local legal systems. Seeking to promote accountability through both punishment and compensation, transnational law litigation posits a broad range of legal responses to violations of international law, initiated and litigated by private and public actors. Such actions help to satisfy the internationally protected right to a remedy for international human rights violations. The evolving notion of universal jurisdiction encompasses jurisdiction over this broad range of legal claims, whether pursued through criminal, civil, or administrative procedures.

U.S. courts and commentators have recognized the application of universal jurisdiction to civil claims. As stated by the Filártiga court itself, "[F]or the purposes of civil liability, the torturer has become-like the pirate and slave trader before him-hostis humani generis, an enemy of all mankind."214 As described in the preceding Section, this concept has been applied to authorize all nations to impose both criminal and civil penalties on those who violated universal norms of international law. ${ }^{215}$ Thus, in the eighteenth and nineteenth centuries, both pirates and slave traders were subject to both criminal prosecution and civil forfeiture of their property. ${ }^{216}$

The Restatement has offered broad support for the application of universal jurisdiction to civil claims, stating in a comment:

Universal jurisdiction not limited to criminal law-In general, jurisdiction on the basis of universal interests has been exercised in the form of criminal law, but international law

214. Filártiga v. Peña Irala, 630 F.2d 876, 890 (2d Cir. 1980).

215. Blum \& Steinhardt, supra note 173 , at 60-61.

216. Id. 
does not preclude the application of non-criminal law on this basis, for example, by providing a remedy in tort or restitution for victims of piracy. ${ }^{217}$

This point has also been reiterated by the U.S. Congress-a report accompanying the Torture Victim Protection Act stated that "according to the doctrine of universal jurisdiction, the courts of all nations have jurisdiction over 'offenses of international concern." court case considering claims of torture, summary execution, and disappearance, the court upheld "the legitimacy of United States jurisdiction over such violations from the perspective of international law" by taking "explicit note" of "the doctrine of universal jurisdiction," which "provides that a "state may exercise jurisdiction to define and punish certain offenses recognized by the community of nations as of universal concern."'219

U.S. commentators have generally agreed. There are several strands to the analysis. As noted, despite the modern focus on criminal prosecutions, actions based on universal jurisdiction historically included civil redress to compensate for injuries inflicted by violations of international norms. Moreover, civil penalties are less onerous than criminal punishment, so that it is logical to conclude that an international law doctrine that affords jurisdiction over the greater sanction necessarily includes the lesser as well. ${ }^{220}$

In addition, international law appears to be less concerned with assertions of civil jurisdiction than with criminal jurisdiction. ${ }^{221}$ Indeed, some commentators have taken the position that international law posits no limits on a state's authority to assert jurisdiction over civil claims. ${ }^{222}$ This view

217. RESTATEMENT (THIRD), supra note 172 , $\$ 404$, cmt. B.

218. S. REP. No. 102-249, at 5 (1992). The report also notes, "States have the option under international law, to decide whether they will allow a private right of action in their courts for violations of human rights that take place abroad." Id. at 3.

219. Xuncax v. Gramajo, 886 F.Supp. 162, 183 n.25 (D. Mass. 1995) (quoting RESTATEMENT (THRD), supra note 172, §404); see also Kadic v. Karadzic, 70 F.3d 232, 240 (2d Cir. 1995) (holding that although universal jurisdiction "is usually exercised by application of criminal law, international law also permits states to establish appropriate civil remedies . ..."); Tel-Oren v. Libyan Arab Rep., 726 F.2d 774, 781 (D.C. Cir. 1984) (Edwards, J., conc.) (interpreting Filártiga as concluding that "persons may be susceptible to civil liability if they commit either a crime traditionally warranting universal jurisdiction or an offense that comparably violates current norms of international law.").

220. Van Schaack, supra note 62, at 195 ("Imposing criminal sanctions on an individual is clearly more intrusive than asserting adjudicatory jurisdiction in a civil action."); Blum \& Steinhardt, supra note 173 , at 86 .

221. Universal jurisdiction over civil actions is "all the more clear because of international law's deference to states in civil actions." James Paul George, Defining Filaritiga: Characterizing International Torture Claims in United States Courts, 2 DICK. J. INT'L L. 1, 32 (1984).

222. Thus, in 1957, Fitzmaurice observed as to jurisdiction over civil matters,

At this point, public international law seems to stop,... for, apparently, public international law does not effect any delimitation of spheres of competence in the civil sphere, and seems to leave the matter entirely to private international law-that is to say in effect to the States themselves for determination, each in accordance with its own internal law...

Gerald Fitzmaurice, The General Principles of International Low, 92 R.C.A.D.I. 1, 218 (1957). Akehurst agreed:

In practice the assumption of [civil] jurisdiction by a State does not seem to be subject to any requirement that the defendant or the facts of the case need have any connection with that State; and this practice seems to have met with acquiescence by other states. . . It is 
seems to go too far, reflecting an overly rigid understanding of the distinction between civil and criminal actions. Nevertheless, the historical view that civil actions were completely unregulated by international law indicates that assertions of civil jurisdiction, at the least, should be less controversial than assertions of criminal jurisdiction. This lends support to the assumption that a system allowing universal jurisdiction over criminal actions permits such jurisdiction over civil actions as well.

Even more important, the rationale behind the international assertion of universal jurisdiction applies to civil claims as well criminal prosecutions. Two main justifications underlie the concept of universal jurisdiction: the abhorrence with which the international community views the wrongs, and the danger that the perpetrator will escape justice by remaining outside the jurisdiction of any state. Both apply equally to civil remedies, which may impose sanctions on the wrongdoer and galvanize international condemnation of the wrongs, as well as deprive the perpetrator of the benefit of his offense and make the victim whole. This point is often misunderstood by observers who assume that the sole purpose of civil tort actions is to obtain monetary compensation for those injured by the tort. While this narrow view of civil litigation may be more accurate in some legal systems, such actions play a far broader role in the United States. Tort claims in the United States serve multiple goals, including retribution and punishment, truth-telling, normdevelopment, and impact on policy debates. These broadly crafted civil actions serve many of the same purposes as criminal actions in other legal systems.

Civil sanctions can also serve an important function in preventing wrongdoers from escaping justice. In instances involving perpetrators who have fled to states where criminal prosecution is impossible, civil claims may be the only means by which the victims and survivors of their abuses can seek redress. In the United States, for example, criminal prosecutions must be initiated by the government and must be based upon a specific statute. Torture committed outside of the United States only became a crime in 1994; criminal charges cannot be brought for such acts committed prior to that date. In addition, the federal government has been frustratingly slow to pursue criminal charges even where the law applies. ${ }^{223}$ As a result, civil litigation is often the only possibility open to victims of human rights abuses.

hard to resist the conclusion that ... customary international law imposes no limits on the jurisdiction of municipal courts in civil trials.

Akehurst, supra note 89, at 177 (footnotes omitted). Akehurst notes that, in practice, states have claimed civil jurisdiction over "all sorts of cases and parties having no real connection with them and that this practice has seldom given rise to diplomatic protests." Id. at 170. "The acid test of the limits of jurisdiction in international law is the presence or absence of diplomatic protests." Id at 176. At the time Akehurst wrote, almost thirty years ago, there had been very few protests of civil jurisdiction, involving isolated cases or protests of the reasoning used by the court rather than the assumption of jurisdiction.

223. For example, the U.S. recently released a Peruvian accused of torture, despite pleas that he be prosecuted. See Sean D. Murphy, Contemporary Practice of the United States Relating to International Law, 94 AM. J. INT'L L. 516, 536 (2000); State Dept. Helped Peruvian Accused of Torture Avoid Arrest, N.Y. TIMES, Mar. 11, 2000, at A7. 
The developing international jurisprudence regarding accountability, including both punishment of perpetrators and compensation for victims, supports the view that states are obligated to take steps to hold accountable those over whom they can exercise jurisdiction. Each legal system must meet this obligation through actions appropriate to its own domestic procedures, which will, in some circumstances, require civil jurisdiction.

Finally, the comparative analysis developed in preceding Parts of this Article makes clear that international law cannot draw lines based on categories that do not translate directly across national lines. States work within the mandate of accountability and the goals of universal jurisdiction, but "translate" those principles into actions appropriate to their legal systems. As Brownlie has pointed out, "[T]here are no rigid forms of action in international law ....224 Each system identifies domestically appropriate means of implementing obligations, so that the concept of universal jurisdiction as applied in some systems would include civil remedies, while in others it might not.

Several concerns about the application of universal jurisdiction to civil claims reflect translation failures, rather than inherent differences between civil and criminal actions. For example, commentators have argued that criminal prosecutions locate control over such actions in the hands of governments, rather than private citizens, thus avoiding diplomatic turmoil. ${ }^{225}$ This argument, however, misses the wide variety of civil and criminal actions around the world. In many legal systems, private parties can initiate criminal prosecutions; in fact, several of the prosecutions based on universal jurisdiction over the past decade began as private actions. Further, governments have tools at hand to enable them to block private actions that allegedly interfere with foreign policy or diplomatic relations. In the United States, the federal executive branch has often been asked to comment on whether a civil claim trespasses upon the executive branch's foreign affairs powers, and the courts have expressed a willingness to dismiss claims that interfere with foreign policy. ${ }^{226}$

Another objection, noted earlier, is that civil actions trivialize human rights abuses, implying that the harms inflicted can be compensated through a simple monetary payment. This fails to acknowledge the punitive, condemnatory content of tort litigation in the United States. While this use of civil litigation may be less familiar in other domestic legal systems, it reflects an accurate translation of human rights accountability into the legal language of the United States.

224. BROWNLIE, supra note 169 , at 474 ; see also George, supra note 221 , at $28 \mathrm{n} .124$ ("[I]nternational law is a simple interstitial legal system-it expresses norms which in tum imply remedies for violations of those norms; these implicit remedies may exist whether or not the norm has an express remedy.").

225. See, e.g., M.O. Chibundu, Making Customary International Law Through Municipal Adjudication: A Structural Inquiry, 39 VA. J. INT'L L. 1069, 1131-32 (1999).

226. See Koh, supra note 37 , at $2382-94$ (detailing the application of traditional doctrines limiting judicial review to prevent judicial overstepping in international human rights cases). 
Given that the line between civil and criminal is not etched in stone but rather varies from system to system, with each system combining attributes of criminal and civil actions in different permutations, international law cannot distinguish between the various forms of actions in use around the world. Limiting universal jurisdiction to criminal prosecutions would run counter to the basic tenet that international law leaves domestic law systems to implement its mandates in ways appropriate to their internal structures. In cases triggering universal jurisdiction, international law provides the jurisdiction but leaves the prosecuting state broad discretion to supply remedies appropriate to its legal system. ${ }^{227}$ Universal jurisdiction permits states to allow extraterritorial civil claims, just as it permits extraterritorial criminal prosecutions.

The recognition that universal jurisdiction authorizes civil claims for human rights abuses against non-national defendants has important implications for the international jurisdictional framework. Claims that might otherwise be barred by commonly shared principles of jurisdiction will be permitted when alleging violations that trigger universal jurisdiction. Thus, "in cases seeking civil redress to enforce human rights norms, forms of personal jurisdiction that may be considered problematic or exorbitant in other contexts are, in fact, quite in tune with the jurisdictional principles of international law."228 This realization is of current concern as dozens of nations participate in negotiations for an international convention governing civil jurisdiction and enforcement of judgments, a topic taken up in the final Part of this Article. A new convention based on an incomplete understanding of varied domestic remedies would unduly narrow the reach of universal jurisdiction. On the other hand, if the international agreement protects the right to seek civil remedies and facilitates the enforcement of the resulting judgments, it will strengthen an important tool of the burgeoning accountability movement.

\section{A New Convention: Preserving Civil Claims for Human Rights Abuses}

Negotiations for an international convention on jurisdiction and enforcement of judgments are currently underway under the auspices of the Hague Conference on Private International Law. ${ }^{229}$ While such a convention could promote recognition of civil judgments based on universal jurisdiction, it could also deal a serious blow to such claims if it fails to reflect the varied

227. See George, supra note 221, at $28 \mathrm{n} .121$ ("Intemational law provides only the jurisdictional grant for actions under universal jurisdiction; the prosecuting state applies its own remedies.").

228. Van Schaack, supra note 62 , at 196.

229. See Hague Conference on Private International Law, Draft Convention on Jurisdiction and Foreign Judgments in Civil and Commercial Matters, Interim Text, June 20, 2001, available at http://www.hcch.net/e/workprog/jdgm.html [hereinafter Draft Convention on Jurisdiction]. This latest draft of the Convention reflects revisions incorporated at a June 2001 negotiating session. A follow-up session will be held in 2002. See Van Schaack, supra note 62, at 171-193, for a thorough analysis of both the history of the negotiations and the human rights concerns triggered by the proposed draft. 
translations of international accountability principles into domestic legal systems around the world.

The convention aims to facilitate enforcement of foreign judgments in "civil and commercial matters"230 by standardizing rules for asserting jurisdiction. According to the working framework under discussion, states becoming party to the convention would agree to enforce judgments from the courts of other member states as long as jurisdiction was obtained in conformity with the requirements of the Convention. ${ }^{231}$ Certain bases of jurisdiction would be prohibited, while others would be optional: member states could rely upon them, but enforcement of the resulting judgments would be discretionary.

As developed so far, this framework poses the threat that civil human rights litigation based on universal jurisdiction will be swept within the prohibited category. As in cases governed by the European Union's Brussels Convention, the draft Hague Convention would afford jurisdiction over tort claims in the defendant's state of residence, ${ }^{233}$ the state where "the injury arose," or the state where the acts or omissions that caused the injury occurred. ${ }^{234}$ Given the reality that the place of harm is often unavailable to a human rights victim, such rules would generally bar plaintiffs from seeking relief, unless the perpetrator happened to relocate to a forum that was hospitable to tort claims of this kind. ${ }^{235}$ The difficulty in bringing suit in the home forum has led to reliance on universal jurisdiction in many human rights cases. ${ }^{236}$ However, early debates about the convention made no reference to this well-accepted international doctrine, presumably because many participants viewed universal jurisdiction as limited to criminal prosecutions and thus irrelevant to a convention governing jurisdiction over civil claims.

230. Draft Convention on Jurisdiction, supra note 229, art. 1. The draft excludes certain matters such as "the status and legal capacity of natural persons," matrimonial property, wills, and insolvency. Id. art. 1(2).

231. Id. arts. 24-26.

232. Id. arts. 17-18, 23-26. Negotiators have hit snags over the issues surrounding intellectual property and electronic commerce, as well as a general U.S. unease with the breadth of the draft convention's provisions; as a result, the future of the negotiating process is unclear. See Arthur T. Von Mehren, Drafting a Convention on International Jurisdiction and the Effects of Foreign Judgments Acceptable World-Wide: Can the Hague Conference Project Succeed?, 49 AM. J. CoMP. L. 191 (2001) (detailing disagreements between the U.S. approach and that favored by European Union States).

233. Draft Convention on Jurisdiction, supra note 229, art. 3.

234. Id art. 10 ("A plaintiff may bring an action in tort in the courts of the state ... in which the injury arose, unless the defendant establishes that the person claimed to be responsible could not reasonably foresee that the act or omission could result in an injury of the same nature in that state.").

235. If the state in which "the injury arose," id., is interpreted broadly to include the place where the victim suffered emotional or physical injuries as a result of a human rights violation committed in another forum, the victim might be able to sue in the forum to which he or she has relocated.

236. Within some domestic legal systems, the same result can be obtained by relying on transient jurisdiction or "doing business" jurisdiction, both of which are prohibited by the current Hague proposals. See Draft Convention on Jurisdiction, supra note 229, arts. 18(e) (prohibiting jurisdiction based on "the carrying on of commercial or other activities by the defendant in that State . . except where the dispute is directly related to those activities"); $18(2)$ (i) (prohibiting jurisdiction based on "the temporary residence or presence of the defendant in that State"). 
If enacted without a special provision governing claims subject to universal jurisdiction, the convention could prohibit many civil claims for human rights abuses, and could deny such claims the advantages of the convention's enforcement procedures. This would bar not only core Filártiga claims such as those litigated in the United States, but also civil claims attached to criminal prosecutions-where based on universal jurisdiction, these would presumably be subject to the same limitations.

The initial drafts of the convention made no provision for human rights litigation. Indeed, negotiators seemed unaware of the role of civil claims in enforcing human rights protections or the possibility that civil litigation might trigger universal jurisdiction. Human rights advocates concerned about the potential impact of such a convention formed a coalition that has participated in the negotiations since the June 1999 negotiating session. ${ }^{237}$ Coalition members discussed two approaches to remedy the human rights problem: to exclude human rights claims from the convention or to create a different set of rules for such cases. The latter approach has gained favor, in part because a total exclusion would also deprive human rights judgments of the benefit of the convention's enforcement provisions.

The coalition found some support among delegates for the concept that human rights claims should not be swept into the convention with the same status as other tort claims. ${ }^{238}$ Language creating a special set of rules for human rights litigation has been included within the latest draft, but the clause is included within brackets, signifying that there is still no consensus about including it at all, much less about the content of such a provision. ${ }^{239}$ The current working draft states:

Nothing in this article shall prevent a court in a Contracting State from exercising jurisdiction under national law in an action claiming damages in respect of conduct which constitutes

(a) genocide, a crime against humanity or a war crime; or

(b) a serious crime under international law, provided that this State has exercised its criminal jurisdiction over that crime in accordance with an international treaty to which it is a Party and that claim is for civil compensatory damages for death or serious bodily injury arising from that crime. ${ }^{240}$

237. Van Schaack, supra note 62 , at 182.

238. In an initial advance, coalition representatives successfully convinced some delegates that civil and criminal responses to international human rights abuses share a common foundation:

$[1] \mathrm{t}$ is only to be expected that criminal proceedings may be accompanied by civil proceedings instituted by victims to obtain relief from the person responsible for the [human rights] violations. In this regard, it should also be noted that a civil action of this kind may be taken in the context of the criminal action itself if national law permits this $\ldots$ otherwise, an action may be instituted independently in a civil court.

Peter Nugh \& Fausto Pocar, Hague Conference on Private International Law, REPORT OF THE SPECIAL COMMIssion 80 (Preliminary Document No. 11), available at http://www.hech.net/el workprog/jdgm.html (last visited Mar. 13, 2001).

239. Draft Convention on Jurisdiction, supra note 229, art. 18(3).

240. Id. 
This proposal is quite restrictive, limiting protected civil claims to genocide, crimes against humanity, war crimes, and those specified by an international treaty and incorporated into national law. As Van Schaack argues convincingly, a human rights exception must allow for flexible future development of the law. Much of what is currently considered to be within the central core of human rights protections has been developed and refined over the past ten years, and is governed by customary international law, not treaty law. Restricting the exception to treaty law would prevent the natural evolution of universal jurisdiction and international human rights law. ${ }^{241}$

To respond to these concerns, the human rights coalition proposed the following language:

Nothing in this Article shall prevent a party from bringing an action in a national court
seeking relief for a violation of international human rights or international humanitarian
law that amounts to criminal conduct under either international or national law, or for
which a right to reparation is established under either international law or national law. ${ }^{242}$

This language was the product of extensive international debate. It addresses concerns about incorporating future developments under both international and domestic law. Moreover, a narrower exception may well conflict with other obligations under international law. International law permits states to allow civil claims for human rights violations. To conform to this law, a new convention must recognize that the definitions of such claims will grow and develop under customary international law and domestic law as well as through treaties. ${ }^{243}$

The difficult negotiations over this provision reflect the international failure to recognize that civil claims represent a domestic law translation of international accountability principles. A comparative perspective on domestic remedies recognizes the importance of civil human rights claims in national

241. A somewhat broader provision was deleted from the most recent draft. It would have extended the exception in some circumstances to "a serious crime against a natural person under international law" or "a grave violation against a natural person of non-derogable fundamental rights under international law, such as torture, slavery, forced labor, and disappeared persons." See Van Schaack, supra note 62 , at 188.

242. Van Schaack, supra note 62, at 184 n.234 (citing SPECIAL COMM'N ON INT'L JURISDICTION AND THE EFFECTS OF FOREIGN JUDGMENTS IN CIV. AND COM. MATTERS, HAGUE CONF. ON PRIVATE INT'L LAW, REPORT OF MEEIING NO. 75, at 2-3 (Oct. 27, 1999) (presentation and discussion of Working Document No. 242)).

243. The possibility of an open-ended human rights exception, however, has triggered concerns about creating a "virtually indefinite" breach in the treaty regime. A U.S. representative participating in the negotiations expressed this objection:

[T]he human rights exception poses special policy problems that are likely to prevent acceptance of the convention in the United States if not adequately addressed in the text. While it is possible that the international human rights organizations may at some point be prepared to agree to limit the exception so that it does not encompass a virtually indefinite spectrim of social and economic rights, I would be surprised if they are satisfied that the draft adequately covers fundamental human rights claims.

Letter from Jeffrey D. Kovar, Assistant Legal Adviser, U.S. Dep't of State, to Alasdair Wallace, Head of International and Common Law Services Division, U.K. Lord Chancellor's Dep't (Sept. 10, 2000), quoted in Sean D. Murphy, Contemporary Practice of the United States Relating to International Law, 95 AM. J. INT'L L. 387, 421 (2001). 
legal systems. This in turn demonstrates the importance of protecting such remedies in any new international agreement, at a minimum recognizing universal jurisdiction over human rights cases, whether the claims are attached to criminal prosecutions or asserted through independent civil actions.

\section{CONCLUSION}

Efforts to move the legal profession beyond the parochial study of individual legal systems toward a global perspective generally focus on the study of international law, the common principles that apply to all of us. But this approach leaves an important gap: we learn little about each other's domestic laws. Neither international lawyers nor human rights specialists are particularly schooled in comparative law. Modern efforts to strengthen the enforcement of international law, however, rely heavily on domestic legal systems. The gap in our comparative law training is increasingly problematic as we attempt to understand, critique, and strengthen the domestic application of international law.

Cross-cultural efforts to coordinate human rights litigation strategies suffer from this lack of a comparative law perspective and the resulting translation failures. Human rights litigators in many countries have developed varied litigation strategies as a tool to promote human rights, without recognizing the common characteristics of our work. At the same time, we have been critical of the choice of litigation strategies in distinct legal systems, without understanding the differences that make universally acceptable models unlikely, if not impossible. Our different legal languages, improperly translated, have interfered with our understanding of the alternative applications of our shared accountability mandate.

A full understanding of the varied options available in differing legal systems is an essential foundation for the worldwide drive for accountability and redress. From this comparative vantage point, we can properly interpret the varied legal approaches adopted in domestic legal systems as domestic translations of international accountability principles. With this understanding, we can forge international agreements that strengthen accountability mechanisms. We thereby further our common goal, a goal understood in any legal language: to develop effective mechanisms for punishing those who violate fundamental human rights, to deter future human rights violations, and to provide redress to victims of human rights abuses. 
